
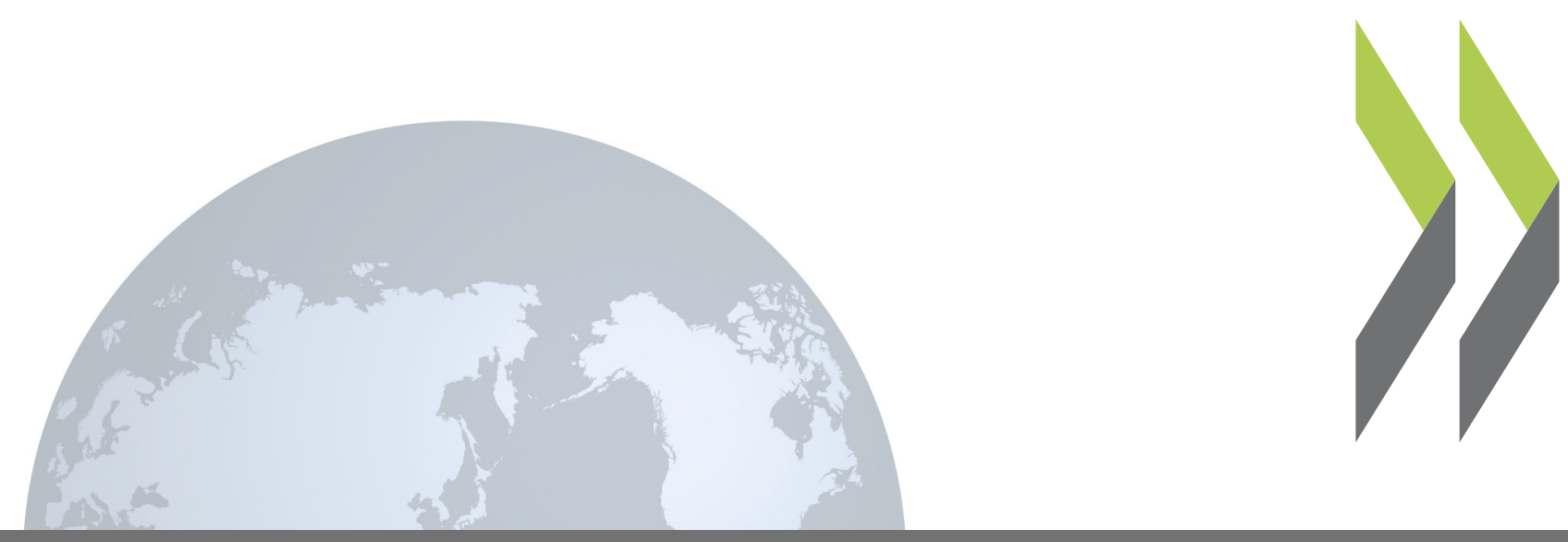

OECD Economics Department Working Papers No. 1310

\title{
The effects of reform
} scenarios for unemployment benefits and social assistance on financial incentives to work and poverty in Lithuania

\section{Jekaterina Navicke,} Silvia Avram,

\section{Lilas Demmou}


Organisation de Coopération et de Développement Économiques

Organisation for Economic Co-operation and Development

21-Jul-2016

ECONOMICS DEPARTMENT

English - Or. English

Cancels \& replaces the same document of 04 July 2016

THE EFFECTS OF REFORM SCENARIOS FOR UNEMPLOYMENT BENEFITS AND SOCIAL ASSISTANCE ON WORK INCENTIVES AND POVERTY IN LITHUANIA

ECONOMICS DEPARTMENT WORKING PAPERS No. 1310

By Jekaterina Navickè, Silvia Avram and Lilas Demmou

OECD Working Papers should not be reported as representing the official views of the OECD or of its member countries. The opinions expressed and arguments employed are those of the author(s)

Authorised for publication by Robert Ford, Deputy Director, Country Studies Branch, Economics Department.

All Economics Department Working Papers are available at www.oecd.org/eco/workingpapers

JT03399427

Complete document available on OLIS in its original format

This document and any map included herein are without prejudice to the status of or sovereignty over any territory, to the delimitation of international frontiers and boundaries and to the name of any territory, city or area. 
OECD Working Papers should not be reported as representing the official views of the OECD or of its member countries. The opinions expressed and arguments employed are those of the author.

Working Papers describe preliminary results or research in progress by the author(s) and are published to stimulate discussion on a broad range of issues on which the OECD works.

Comments on Working Papers are welcomed, and may be sent to OECD Economics Department, 2 rue André Pascal, 75775 Paris Cedex 16, France, or by e-mail to eco.contact@oecd.org.

All Economics Department Working Papers are available at www.oecd.org/eco/workingpapers.

This document and any map included herein are without prejudice to the status of or sovereignty over any territory, to the delimitation of international frontiers and boundaries and to the name of any territory, city or area.

The statistical data for Israel are supplied by and under the responsibility of the relevant Israeli authorities. The use of such data by the OECD is without prejudice to the status of the Golan Heights, East Jerusalem and Israeli settlements in the West Bank under the terms of international law.

Latvia was not an OECD member at the time of preparation of this paper. Accordingly, Latvia is not included in the list of OECD countries and is not included in the area totals.

\section{(c) OECD (2016)}

You can copy, download or print OECD content for your own use, and you can include excerpts from OECD publications, databases and multimedia products in your own documents, presentations, blogs, websites and teaching materials, provided that suitable acknowledgment of OECD as source and copyright owner is given. All requests for commercial use and translation rights should be submitted to rights@oecd.org 
ECO/WKP(2016)34

\author{
Abstract/Résumé \\ The effects of reform scenarios for unemployment benefits and social assistance \\ on financial incentives to work and poverty in Lithuania
}

In 2015 the Lithuanian government launched an ambitious Social Model reform agenda aimed at balancing flexibility of the labour market and security provided through the system of social protection. We simulate alternative scenarios for reforming the unemployment benefit and cash social assistance systems in Lithuania. We first analyse a reform of the social insurance unemployment benefit along the lines currently proposed by the Lithuanian authorities within the new "Social Model". The social assistance reforms were left outside of the Social Model. However, social assistance, as currently designed, has strong negative effects on the work incentives of the recipients. We construct and consider several reform scenarios: extending the current system of in-work payments; establishing earnings disregards; and modifying the equivalence scale for family. We look at the effects of reforms on financial incentives to search and accept a vacancy as measured by the share of additional income that is taxed away through direct taxes, social insurance contributions or through benefit withdrawal when increasing labour supply (effective marginal tax rate). We also investigate the impact of reforms on poverty, income distribution as well as their first-order financial costs. We use microsimulation techniques applied to a representative sample of Lithuanian households. Our simulations are carried out using EUROMOD - a static tax-benefit microsimulation model developed for the European Union. The model uses micro-data from the 2012 Lithuanian component of the European Union-Survey of Income and Living Conditions (SILC).

This Working Paper relates to the 2016 OECD Economic Survey of Lithuania (www.oecd.org/eco/surveys/economic-survey-lithuania.htm).

Key words: Unemployment benefits, social assistance benefits, in-work benefits, simulations, Effective tax rate, Survey on Income and Living conditions (SILC), EUROMOD

JEL: J2, I3, J6, D3, D04

$$
* * * * * *
$$

Les effets de différents scénarios de réforme des assurances chômage et aides sociales sur les incitations financières au travail et la pauvreté en Lituanie

En 2015, le gouvernement Lituanien a lancé un programme de réforme ambitieux du modèle social visant à trouver un équilibre entre flexibilité de la législation du marché du travail et sécurité fournie par le système de protection sociale. Nous simulons des scénarios alternatifs de réformes des allocations d'assurance chômage et du régime d'aide sociale (allocations payées sous forme d'aide en liquidités) en Lituanie. Nous analysons d'abord les effets d'une réforme de l'allocation d'assurance chômage selon les lignes actuellement proposées par les autorités lituaniennes dans le cadre du nouveau «Modèle Social ». Ce nouveau modèle social ne prévoit pas de reformes de l'aide sociale. Toutefois, le régime d'aide sociale, tel qu'il est actuellement conçu, a des effets fortement négatifs sur les incitations au travail des bénéficiaires. Nous construisons et considérons plusieurs scénarios de réforme du régime d'aide social: une extension du système de prestations liées à l'exercice d'un emploi; la mise en place de mesures d'exemptions de rémunération; et une réforme du facteur d'équivalence tenant compte de la taille des familles lors de l'octroi des allocations. Nous examinons les effets des réformes sur les incitations financières à rechercher et accepter un poste tel que mesuré par la part du revenu supplémentaire qui est effectivement imposé via les impôts directs, les cotisations d'assurance sociale ou par le retrait des prestations (taux effectif marginal d'imposition). Nous étudions également l'impact des réformes sur la pauvreté, la répartition des revenus ainsi que leurs coûts financiers (de premier tour). Nous utilisons des techniques de microsimulation appliqués à un échantillon représentatif des ménages lituaniens. Nos simulations sont effectuées à l'aide du modèle statique de micro-simulation des taxes et prestations sociales EUROMOD développé pour l'Union européenne. Le modèle utilise des micro-données tirées de l'enquête de l'Union Européenne sur les conditions de revenu et de vie (SILC) 2012.

Ce document de travail se rapporte à l'Étude économique de l'OCDE de la Lituanie 2016 (www.oecd.org/fr/eco/etudes/etude-economique-lituanie.htm).

Mots clés: Allocation d'assurance chômage, aide sociale, prestations liées à l'exercice d'un emploi, simulations, taux de taxation effective, Enquête sur le revenu et les conditions de vie (SILC), EUROMOD.

Classification JEL : J2, I3, J6, D3, D04 
TABLE OF CONTENTS

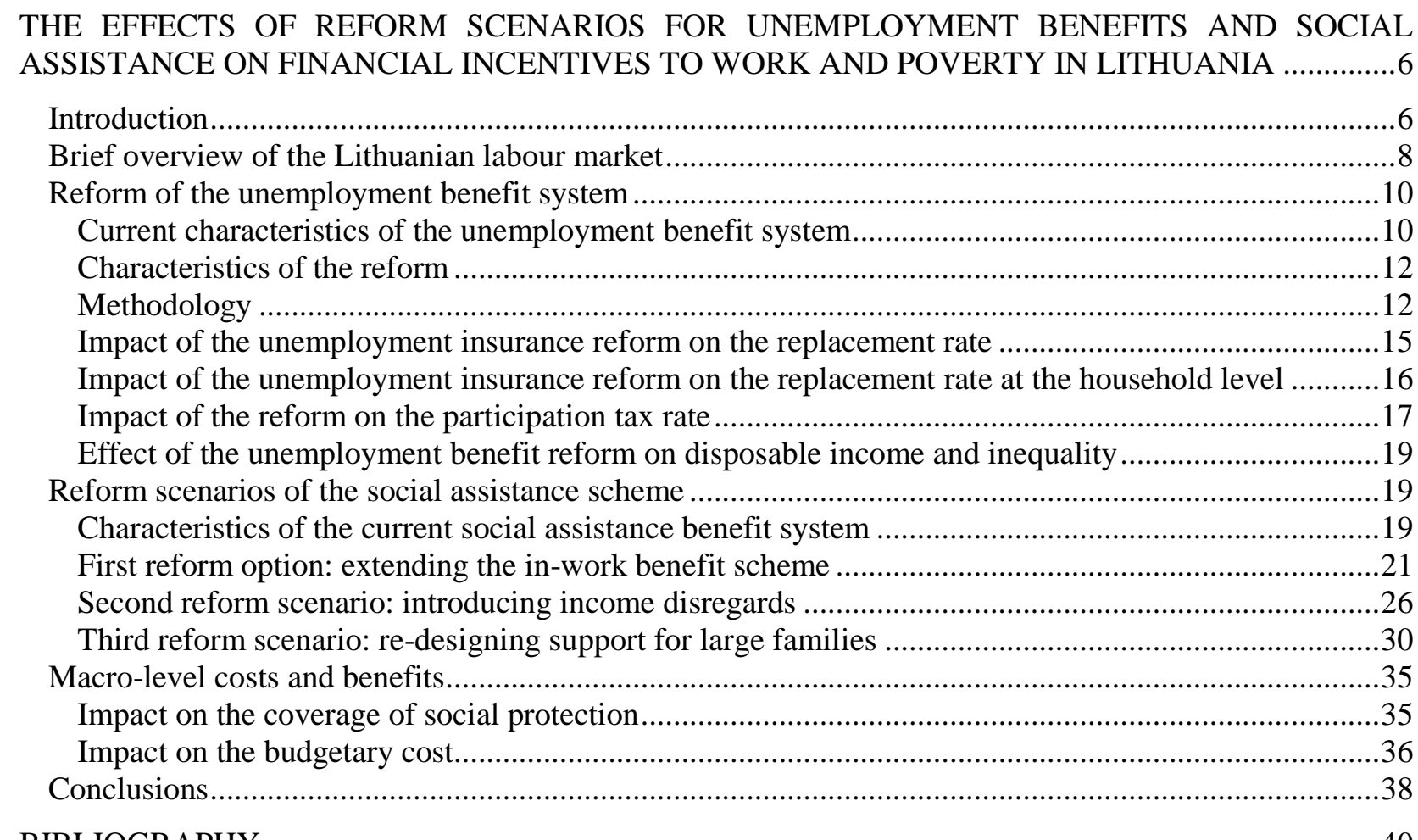

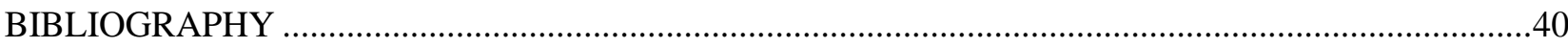

ANNEX 1: CHARACTERISTICS OF THE CURRENT SYSTEM OF SOCIAL ASSISTANCE, SYSTEM

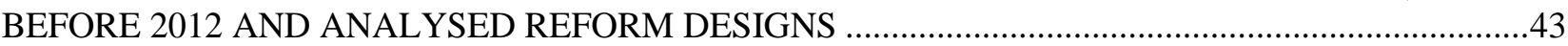

ANNEX 2: INDICATORS OF FINANCIAL INCENTIVES TO WORK AT THE EXTENSIVE

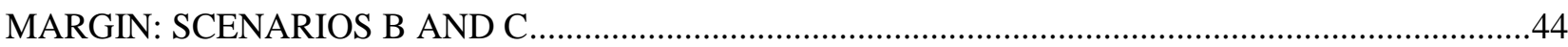

\section{Tables}

1. Characteristics of the current and proposed model........................................................................12

2. Average national gross wage - all economy with individual enterprises, in EUR ................................12

3. Mean and cut point of net earnings' quintiles in EUR per month: ................................................. 16

4. Recipients and expenditure on cash social assistance and additional payments for long-term SA

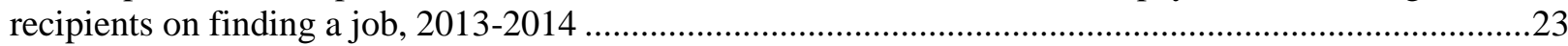

5. Recipients of cash social assistance and additional payments for long-term recipients on finding a job, 2014

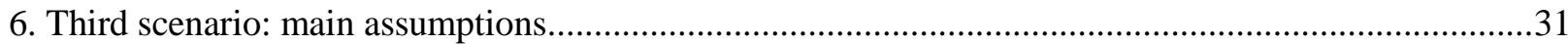

7. State supported income as $\%$ of the median eq. household disposable income and monthly minimums salary...... 


\section{Figures}

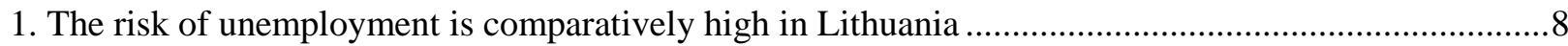

2. The social assistance system is an important income buffer for joblessness ......................................10

3. NRR1s for unemployment benefits by earnings quintile and month of receipt before and after the

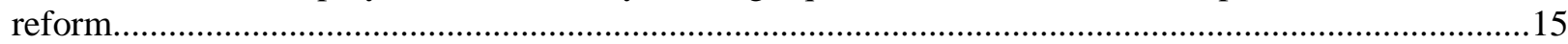

4. Average annual NRR1s for unemployment benefits by earnings quintile before/ after the reform and

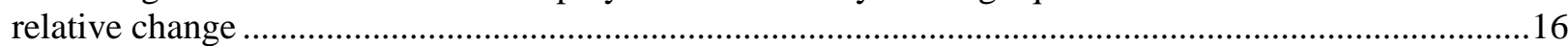

5. Total annual NRR2s by quintile of earnings before and after the reform.......................................17

6. Average annual PTRs before and after the reform by earnings decile and by family type ...................18

7. Change in the total household disposable income by income decile ................................................19

8. Number of recipients and total expenditure on social assistance in-work payments ...........................22

9. Change in amounts of social assistance with growth in net earnings for singles and couples previously

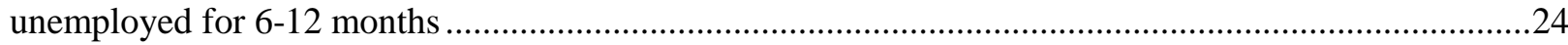

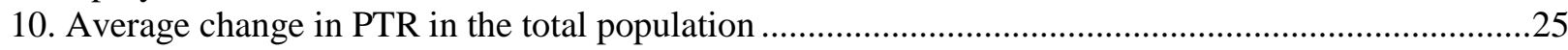

11. Change in the household disposable income by income deciles...................................................25

12. Change in amounts of social assistance with growth in net earnings for singles and couples.............27

13. METR among those with positive employment income and among social assistance recipients,

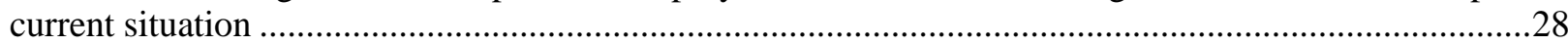

14. Change in the marginal effective tax rates among social assistance recipients by family type ...........29

15. Change in the marginal effective tax rates by income decile..........................................................29

16. Changes in the eq. household disposable income due to reform by deciles of household disposable

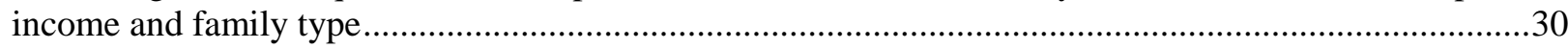

17. Change in amounts of social assistance with growth in net earnings for singles and couples..............33

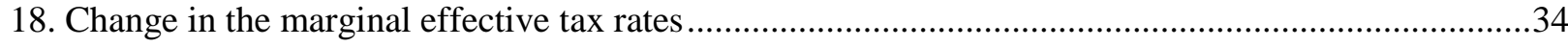

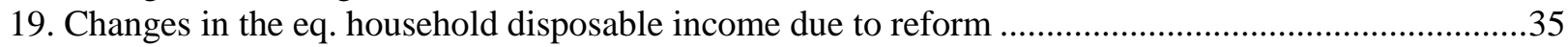

20. Effects of different scenarios on the number of recipients of out-of-work benefits ............................36

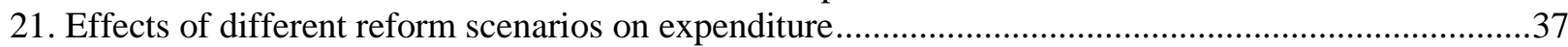

22. Potential effects of the reform scenarios on the at-risk-of-poverty gap, rate and inequality ................38

\section{Boxes}

Box 1. Unemployment social insurance benefit in Lithuania (current - as of December $\left.1^{\text {st }} 2015\right)$...........11

Box 2. Measures of financial incentives to take a job for unemployed ................................................14

Box 3. Social assistance benefit in Lithuania (as of December $\left.1^{\text {st }} 2015\right)$.................................................20

Box 4. Measures of work incentives for social assistance recipients ..................................................21 


\title{
THE EFFECTS OF REFORM SCENARIOS FOR UNEMPLOYMENT BENEFITS AND SOCIAL ASSISTANCE ON FINANCIAL INCENTIVES TO WORK AND POVERTY IN LITHUANIA
}

\author{
by Jekaterina Navickè, Silvia Avram and Lilas Demmou ${ }^{l}$
}

\section{Introduction}

1. With one out of five persons at risk of poverty, fighting poverty and inequality is a major challenge in Lithuania. A starting point to promote inclusiveness is to establish institutions that are conducive to better labour market performances as being in work is often an important way to exit poverty (OECD, 2015). The design of out-of-work benefits is especially important as they provide a minimum income buffer and affect participation in the labour market which is an important factor to exit poverty (OECD, 2015). Out-of-work benefits should optimally provide both adequate levels of social protection and sufficient financial incentives to work (Immervoll and Pearson, 2009). Against that background this paper discusses potential directions for reforming unemployment insurance and social assistance benefits in Lithuania.

2. In 2015 the Lithuanian Ministry of Social Security and Labour commissioned a group of researchers from the three major Lithuanian academic institutions to analyze potential reforms of the system of social protection (Vilnius University, Mikolas Riomeris University, Lithuanian Social Research Centre; see Socialinis modelis, 2015). The result is a set of reform proposals collectively called the new Social model for Lithuania. The proposed reform is aimed at increasing the flexibility of the Lithuanian labour market through a more liberal labour code, while providing more security through the system of cash social benefits, social insurance benefits in particular. The first contribution of this paper is to present the potential impact of a reform of unemployment benefit system along the lines planned by the authorities. We especially look at the impacts on the replacement rate, the incentives to work and income inequality.

3. The sphere of social assistance remains outside of the reform package, as an important reform was already implemented in 2012. However, additional directions for reform are discussed considering the high level of poverty in Lithuania and the importance of the social assistance system in shaping work incentives for those with the lowest incomes. ${ }^{2}$ Previous research on Lithuania suggests that financial incentives to work more (measured by effective taxation) are relatively high in the middle and upper part of the Lithuanian income distribution and are substantially lower for people in the lower income quintiles (Tamašauskienė 2003, Lazutka \& Poviliūnas 2010, UNDP 2010, Lazutka et al. 2013, Jara \& Tumino 2013, Navicke \& Lazutka 2015). Such a regressive profile of work incentives is not atypical in comparative perspective (see e.g. Jara \& Tumino 2013). It is due mainly to the withdrawal of cash social assistance benefits when income increases, a narrow gap between in-work income and cash benefit provisions and flat tax-rate systems of personal income taxation and social insurance contributions (Navické \& Lazutka 2015). The second contribution of this paper is to analyse possible reforms of cash social assistance benefits in Lithuania aimed at delivering stronger support for the most in need while providing stronger incentives to participate in the labour market (i.e. by allowing recipients to keep a larger share of the extra earned income and making work pay). We consider three reforms scenario of the social assistance benefit system characterized by different parameters regarding the coverage, the level of benefits and the design of in-work benefits. In the first scenario, we examine an extension of in-work payments for social assistance

1. Jekaterina Navicke is researcher at Vilnius University, Silvia Avram is researcher at Essex University and Lilas Demmou is senior economist at the OECD. The authors would like to thank for their comments Herwig Immervoll, Nicolas Ruiz, Ann Vourch, Ben Westmore and Andreas Wörgötter. Special thanks to Corinne Chanteloup, Sisse Nielsen and Heloise Wickramanayake for statistical and editorial support.

2. Details on the reform can be found in Lazutka (2014). 
recipients; in the second scenario we look at the introduction of income disregards and in the last scenario, we investigate the effects of a change in the design of cash social assistance benefits.

4. We estimate the effect of our reforms scenarios on work incentives and on the income distribution using microsimulation techniques applied to a representative sample of Lithuanian households. Our simulations are carried out using EUROMOD version 2.75+ (Sutherland \& Figari 2013). EUROMOD is a static tax-benefit microsimulation model developed for the European Union, which is based on household and individual micro-data and allows for the simulation of direct taxes, social insurance contributions as well as of a large number of benefits, including unemployment benefits and social assistance. Labour market income and other non-simulated income sources are taken directly from the data and updated based on average growth. Information on average growth by income source is obtained from administrative sources or official projections. For our simulations, we use micro-data from the 2012 Lithuanian component of the European Union-Survey of Income and Living Conditions ${ }^{3}$. EUROMOD models the intended functioning of the system as if the reforms were introduced in 2015. As our data refers to a period when Lithuania was still in the midst of the economic and labour market crisis, the estimates of the impact on poverty, inequality and costs of the analysed reforms are presented and should be interpreted in relative terms. Our simulations assume full benefit take-up and tax compliance.

5. EUROMOD is an a static microsimulation model meaning that it helps estimate first-order effects of the reforms assuming that individual behavior will not change as a result of the reform. This approach is standard in the evaluation of distributional changes of tax and benefit reforms and allows highlighting the winners and losers of a reform. The assumption of unchanged behaviors may appear quite restrictive at a first stance but it is fully consistent with the existence of behavioral response under some conditions. It has in particular proven to provide a good approximation of welfare effect when changes are small and individuals are not rational optimizers (Bourguignon and Spadaro, 2006). Behavioral responses may also be limited by demand constraints (for ex: unavailability of part-time jobs, fixed working hours etc.). A large part of our analysis focuses on calculating work incentives, which are generally used to determine behavioral reactions (and so are unaffected by them). However, behavioral responses are likely to be more important when analyzing macro and distributional effects such as budgetary effects or the impact of reforms on poverty rates (based on a pre-determined threshold).

6. We calculate a series of indicators, which are slightly different in the case of the unemployment benefit reform and in the case of social assistance reforms. First, we calculate a series of work incentives indicators. These are net replacement rates (NRRs), participation tax rates (PTRs) and marginal effective tax rates (METRs) ${ }^{4}$. Second, we look at the impact of reforms on the income distribution by looking at three dimensions: disposable income, poverty indicators and GINI indicators.

7. In the next section we present briefly the situation of the labour market in Lithuania and the role played by unemployment and social benefits systems in case of job loss. Next, we present the potential effect of a reform of the unemployment benefit system. In the third section, we discuss the different reform scenarios of the social assistance system. In the case of each reform, we look at the impact on net earnings, work incentives, and disposable income, both at the individual and household levels. Finally we present the potential macro-cost and benefits of those reforms.

3. The current system is simulated as of the $30^{\text {th }}$ of June 2015 .

4. Worth noting that the OECD indicators of work incentives for model families are largely consistent with the EUROMOD-based estimates (Navicke \& Lazutka, 2015). The two sources of information differ, however, as in the first case impact is evaluated among the model families with pre-selected characteristics, while EUROMOD helps model the effect on the actual population as captured by the EU-SILC. 


\section{Brief overview of the Lithuanian labour market}

8. The Lithuanian labour market has been hit hard by the recent economic crisis but has quickly recovered. The unemployment rate has halved since the crisis and it was below 9\% in 2015, after having peaked at $18 \%$ in 2010 . The current level remains higher than the OECD average and the gap is even higher for some specific groups, in particular youth, the low-skilled and seniors. This picture implies that the risk of unemployment is comparatively high in Lithuania. Overall, job destructions during the last financial crisis were large and the unemployment rate follows closely the economic cycle suggesting weak barriers to hiring and firing despite a comparatively restrictive labour code ${ }^{5}$. The relationship between GDP and unemployment changes in Lithuania (so-called Okun's law) is estimated at 0.49 for Lithuania which is similar to the United States (IMF, 2014; OECD, 2016b).

Figure 1. The risk of unemployment is comparatively high in Lithuania

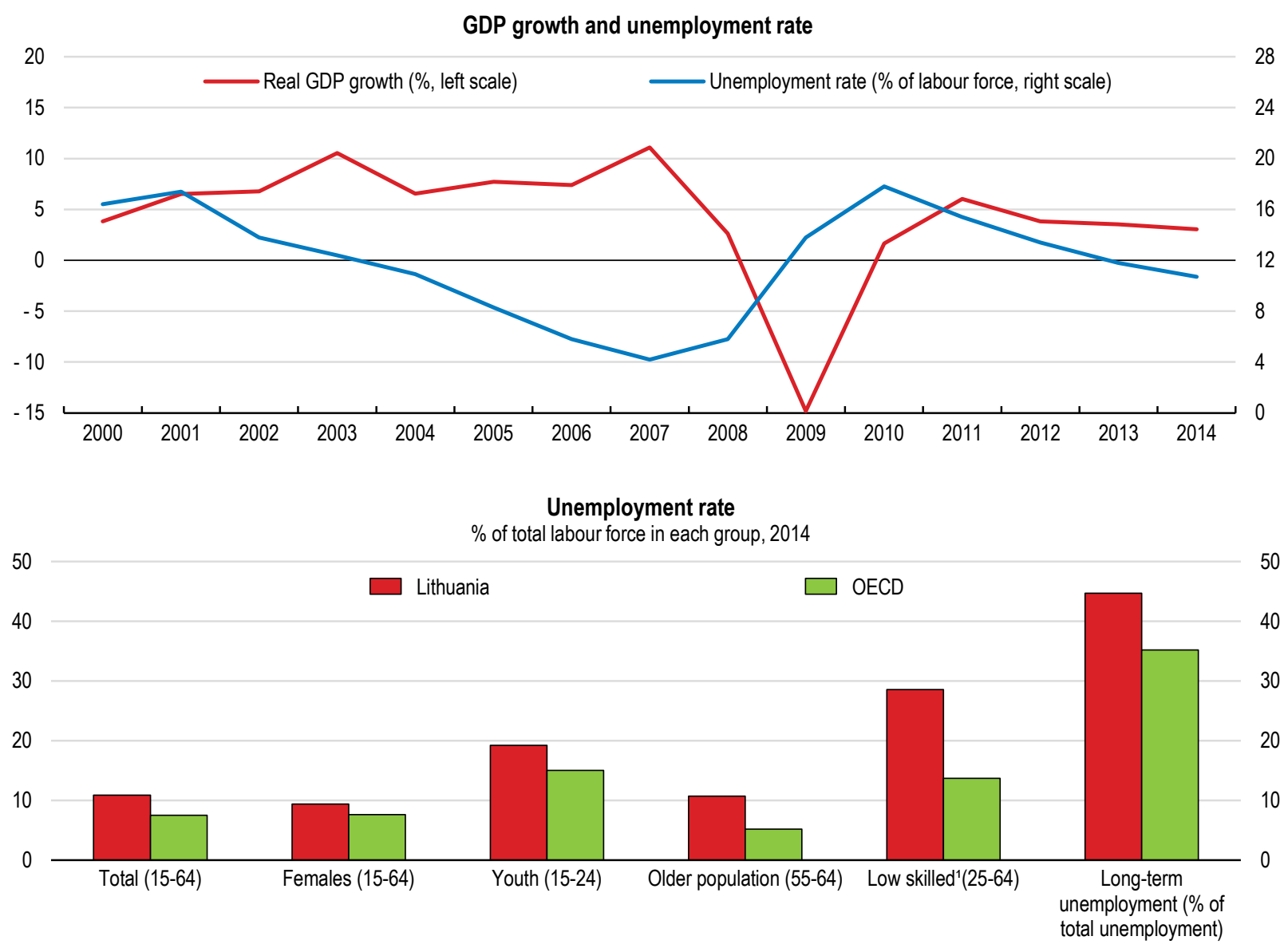

1. 2013 data for OECD (unweighted average).

Source: OECD Economic Outlook 98 database; Statistics Lithuania database; OECD Labour Market Statistics; OECD Education at a glance database; Eurostat LFS Main indicators database.

9. Against that background, the Lithuanian unemployment insurance benefit system provides weak support in case of job loss. It is very restrictive by international standards and combines strict eligibility

5. Legislation is however comparatively restrictive. A discussion on that gap between practice and legislation can be found in Demmou (2016) or OECD (2015b). 
criteria (implying a long minimum contribution period), low duration and a low level of benefits (Lagenbusher, 2015). The average net replacement rate for low-paid earners (67\% of average wage) is for instance on average 55\% compared with an average 63\% in the OECD during the initial year of unemployment. When looking over a five year period, it is on average at $13 \%$ compared with $28 \%$ in the OECD (OECD, 2016). Furthermore, less than $20 \%$ of the unemployed are covered by the unemployment benefit system (chapter 2; Lagenbusher, 2015). Youth and people with interrupted careers in particular encounter more difficulty accessing benefits.

10. Weak income security in the event of job loss contributes to income inequality and vulnerability to poverty (Figari et al. 2011, Navickè 2015, Demmou 2016). The restrictive nature of the system impacts also on the performance of the labour market. A low level of unemployment benefits can boost job-search by reducing the reservation wage, but such a design may also inhibit the functioning of the labour market through several channels. First, unemployment benefits provide financial support to the unemployed who can devote time to looking for a job and/or to finding a job that better matches their skills, thus improving labour market reintegration (Wulfgram and Fervers, 2013; Tatsiramos, 2009). Second, a close link between previous earnings and current benefits could also increase the incentive to take a job in the formal sector in order to benefit from the income security that is associated with formal jobs (OECD, 2008). This is an important issue for Lithuania as recent work suggests that despite falling in recent years, Lithuania's informal economy is one of the largest in the EU (Schneider, 2015). In the midst of the latest economic crisis, income from informal work was evaluated to constitute around 23\% of the Lithuanian shadow economy, which in its turn was estimated at around 30\% of GDP (Socialinis modelis 2015, annex I-7). Finally, better coverage would make the unemployed more readily reachable for public employment services (Immervoll and Scarpetta 2012).

11. With weak unemployment benefits, the social assistance system plays a crucial role in Lithuania. During the latest economic crisis, expenditures both on social insurance unemployment benefits and cash social assistance increased rapidly, mitigating the income shock households faced in the context of rapidly increasing unemployment and economic decline. Unemployment benefits provided initial protection while the cash social assistance system took over this role as eligibility for unemployment benefits ran out and for non-eligible individuals. In effect, the system of social assistance in Lithuania compensated during the crisis for the weakness of the unemployment benefit system (Figure 2). The number of social assistance recipients increased from around 1\% of the total population in Lithuania before the crisis to around $7 \%$ at its peak in 2011-2012 and reduced gradually to around 5\% thereafter. By contrast, the number of unemployment benefit recipients remained relatively stable. While the number of social assistance and unemployment benefits recipients in Lithuania are still above the levels observed before the crisis, the total amounts spent on unemployment benefits and cash social assistance in Lithuania as a share of GDP remain well below the average levels observed in the EU. 
Figure 2. The social assistance system is an important income buffer for joblessness

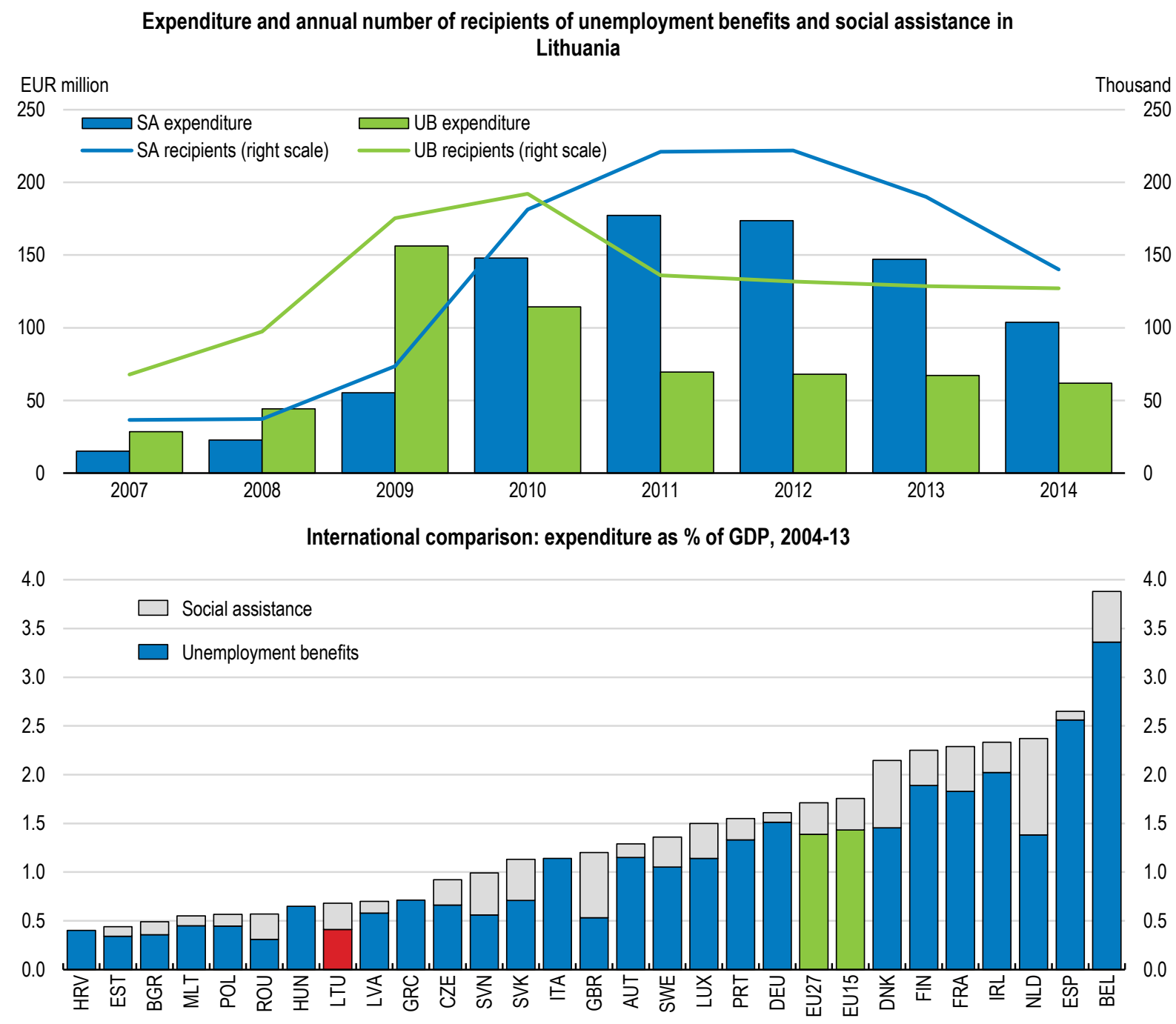

Notes: UB - cash unemployment benefits, SA- cash social assistance (social exclusion n.e.c. Years excluded if data not available. Averaging across the last decade helps eliminate the volatility of expenditures on cash social benefits due to the recent crisis across the EU.

Source: Eurostat [social exclusion n.e.c. - cash benefits: spr_exp_fex], [unemployment - cash benefits: spr_exp_fun]. Extracted on $12 / 23 / 2015$.

\section{Reform of the unemployment benefit system}

\section{Current characteristics of the unemployment benefit system}

12. The unemployment benefit systems contains a redistributive element due to a fixed basic part, which is estimated in relation to the State Supported Income (SSI) - a parameter also used as a base for the estimation of social assistance benefits in Lithuania. As a result, the replacement rate decreases as previous earnings increase. This ensures a relatively high replacement rate in the lower part of the income distribution. The variable part of the benefits provides a link with previous earnings, although its initial replacement rate is low at $40 \%$ and reduces to $20 \%$ of the previous insured income after three months (see Box 1). Weak links between the level of previous earnings and unemployment benefit payments in 
Lithuania result in a relatively high financial incentive to take a job especially in the middle and higher part of the distribution. At the same time, such a design compromises benefit adequacy, can result in shorter job search and poorer job match, and may also reduce the incentives to participate in the formal labour market.

\section{Box 1. Unemployment social insurance benefit in Lithuania (current - as of December $1^{\text {st }}$ 2015) \\ Eligibility to unemployment benefits}

The unemployment social insurance benefit (nedarbo draudimo išmoka) is organized via a compulsory insurance system and covers individuals receiving remuneration for work. Eligible persons are working age persons, aged 16 up to the statutory retirement age. The required insurance record is at least 18 months during the last 36 months and a person must be actively looking for a job.

\section{Duration of unemployment benefits}

The duration of benefit payments depends on the unemployment insurance history:

- 6 months - if the insurance record is less than 25 years;

- 7 months - if the insurance record is between 25 and 29 years;

- 8 months - if the insurance record is between 30 and 34 years;

- 9 months - if the insurance record is 35 years or more.

The duration of the payment can be extended by two months when the unemployed is close the retirement age (no more than five years), or by the duration of the leave when the unemployed has been on sick leave or maternity leave while eligible for unemployment benefit payments.

\section{Level of unemployment benefits}

The monthly benefit amount $(U)$ comprises fixed $(F)$ and variable $(V)$ components $(U=F+V)$. The fixed benefit component is equal to the State supported income (SSI) and the variable benefit component is equal to $40 \%$ of the former insured income.

The level of unemployment benefit is reduced with the duration of the unemployment spell:

- During the first three months $-U$ is paid in full.

- For the remaining unemployment duration period: $U=F+0.5^{*} \mathrm{~V}$ (fixed component plus $50 \%$ of the variable component).

A ceiling for the full unemployment benefit applies, i.e.: $U<=0.7^{\star} \mathrm{CYI}$, where $\mathrm{CYI}$ stands for the level of the current year's insured income set by law. The ceiling is applicable during the entire period of benefit payment. The benefit is not means tested.

Current year's insured income 2011-2015, EUR

\begin{tabular}{lcccccc}
\hline & 2011 & 2012 & 2013 & 2014 & 2015 & 2016 \\
\hline Current year's insured income (CYI) & 339 & 431 & 431 & 431 & 431 & 445 \\
\hline
\end{tabular}

Note: Exchange rate of 3.4528 applied for conversion of the CYI to EUR up to 2015, rounded up values

Unemployment benefits may be received simultaneously with a number of other social insurance benefits but the unemployment benefit is reduced by the amount of these other benefits: state social assistance benefits/pensions or state pensions (except survivor and orphan pensions), work incapacity periodical compensations due to occupational injuries and occupational diseases, vocational rehabilitation, maternity, paternity or maternity (paternity) social insurance benefits. The unemployment benefit cannot be paid together with the old-age pension or early retirement pension.

Source: EUROMOD Country Report for Lithuania. Available at: https://www.iser.essex.ac.uk/euromod/usingeuromod/country-reports 


\section{Characteristics of the reform}

13. The objective of the reform is to strengthen the income protection of the unemployed by increasing the level, the duration and the coverage of benefits (Table 1). The reform aims also at strengthening the links with previous earnings to motivate participation in the formal economy and in the social insurance system in particular.

Table 1. Characteristics of the current and proposed model

\begin{tabular}{|c|c|c|}
\hline & Current system & Planned reform \\
\hline Benefit amount & $\begin{array}{l}\text { Constant part: state-supported income (set at } \\
102 \text { euros) } \\
\text { Variable part: } \\
-40 \% \text { of former earnings during the first three } \\
\text { months } \\
-20 \% \text { of the former earnings after three } \\
\text { months. }\end{array}$ & $\begin{array}{l}\text { Constant part: } 30 \% \text { of the minimum monthly wage } \\
\text { Variable part: } \\
\text { - } 50 \% \text { of former earnings during the first three } \\
\text { months } \\
-40 \% \text { between the fourth and sixth month, } \\
-30 \% \text { between the seventh and ninth month }\end{array}$ \\
\hline Benefit ceiling & $70 \%$ of CYI (see Box 1) & $75 \%$ of the gross average wage (see Table 2 ) \\
\hline Duration & $\begin{array}{l}\text { - } 6 \text { months - if the insurance record is less } \\
\text { than } 25 \text { years; } \\
\text { - } 7 \text { months (insurance record } 25-29 \text { years); } \\
\text { - } 8 \text { months (insurance record } 30-34 \text { years); } \\
\text { - } 9 \text { months (insurance record } 35+\text { years). } \\
+ \text { extra } 2 \text { months for special groups }\end{array}$ & $\begin{array}{l}9 \text { months } \\
+ \text { extra } 2 \text { months for special groups }\end{array}$ \\
\hline $\begin{array}{l}\text { Required } \\
\text { contribution history }\end{array}$ & 24 months during the previous 36 months & 12 months during the last 24 months \\
\hline
\end{tabular}

Table 2. Average national gross wage (ANGW) - all economy with individual enterprises, in EUR

\begin{tabular}{l|c|c|c|c|c|c}
\hline & $2014 q 1$ & $2014 q 2$ & $2014 q 3$ & $2014 q 4$ & $2015 q 1$ & $2015 q 2$ \\
\hline ANGW & 655.3 & 667.1 & 681.4 & 699.2 & 686.4 & 700.9 \\
\hline
\end{tabular}

Source: Statistics Lithuania - http://osp.stat.gov.lt/ [accessed on 2015.11.09]

\section{Methodology}

14. To understand the work incentives provided by the unemployment benefit system, we first show net replacement rates provided by unemployment benefits relative to lost earnings (NNR1), both for the current system and the proposed reform. This provides information on the wage level relative to the previous wage at which it would make financial sense to enter new employment while in receipt of unemployment benefits. We also discuss interactions with other elements of the tax benefit system and other market incomes by providing the overall net replacement rates (NNR2), i.e. calculating the proportion of previous disposable income that is kept when unemployed and showing which sources of income play the most important role in providing resources to the unemployed. Next, we look at the participation tax rates (PTRs) which can be interpreted as the fraction of earnings taxed away through taxes, social insurance contributions and withdrawal of benefits if the unemployed person finds a job with a salary level equal to earnings before unemployment. Both NRR2 and PTR indicators are calculated as yearly averages and take into account all income sources of all the household members, including the unemployed person.

15. The main difficulty for the simulations is to compare the income of individuals when they are at work with their potential revenue when unemployed. This requires having information on the eligibility of each worker to unemployment benefits and their level of earnings and to make assumptions on the length 
of unemployment for individuals who lose their jobs. In the dataset we observe periods of employment, unemployment and inactivity only during a year, we do not observe a wage for individuals who are currently unemployed and we do not have information on the contribution records over the qualifying period (36 months). Hence, we make the following assumptions:

- We can only calculate replacement rate for individuals who are employed for some period in our dataset. This allows us to avoid estimating shadow wages for people who are not in employment (and whose potential wage is thus unobserved). It should be acknowledged that excluding those with no observed earnings may results in a biased estimate of work-incentive indicators in the total population as the potential earnings of this group can systematically differ compared to those with observed earnings. While we do not correct for the potential selection bias, the work incentives are disaggregated into five quintiles by earnings size. The level of employment in the reference year of our data (2012 SILC refers to 2011 incomes) was at $66.9 \%$ compared to $73.4 \%$ in the target year of simulations, i.e. $2015^{6}$.

- We assume that the length of the unemployment spell is equal to that of the observed spell of employment, i.e. periods of inactivity are unaltered and periods of unemployment in the baseline become periods of inactivity. We simulate tax liabilities, benefit entitlements and household disposable income for each individual who is observed to be in employment for at least 1 month in our dataset. We then re-compute the same tax liabilities, benefit entitlements and household disposable income under the assumption that the person becomes unemployed for the same amount of time she has been observed in employment.

- One way EUROMOD simulations get around the problems of unobserved contribution histories is to assume that the observed insurance record within the 12 months is proportional to the whole qualifying period. In our case however, this assumption is not sufficient as both the currently required insurance record (18 months within the last 36 months) and that of the reformed system (12 months within the last 24 months) constitute half of the total qualifying period. To overcome this limitation and in absence of administrative data on the distribution of the insurance records among the unemployed, we make the following assumptions. First, based on the data from the latest wave of the longitudinal EU-SILC component for Lithuania, the share of those with an insurance record between 12 and 18 months was calculated among those who become unemployed in the final year of the panel. While the share of people with such insurance records may differ along a number of characteristics (e.g. age, region, sphere of employment), we disaggregate only by education and gender, as these two dimensions proved to be the most salient. A more detailed split was not possible due to too low sample sizes observed in the data. Using this information, we then randomly select in our data individuals who are unemployed but not entitled to unemployment benefits under the current system to be eligible for unemployment benefits in the reform system (i.e. $23 \%$ of males with non-tertiary education, $5 \%$ of females with tertiary education and $10 \%$ of males with tertiary education and females with non-tertiary education).

6. Eurostat (2016). Employment and activity - LFS adjusted series [lfsi_empl]. Database. Online source [accessed on 17/05/2016]. 


\section{Box 2. Measures of financial incentives to take a job for unemployed}

1) NRR1: The level and change in the share of lost earnings replaced by the unemployment benefit across five quintiles of individual earnings

$N R R 1_{i}=U B_{i} / E_{i}$, for every employed individual $i$ in our dataset, where UB=individual unemployment benefit and $E$ =individual gross earnings. We obtain $U B_{i}$ by simulating the amount of unemployment benefit an individual would be entitled to should she become unemployed. We simulate both eligibility and the amount of unemployment benefits a person is entitled to for every month of the unemployment spell up to a maximum of 12 months, as well as the average yearly entitlement.

2) NRR2: The level and change in the share of household disposable income when the person is employed that is kept when the person becomes unemployed

$N R R 2_{i}=\operatorname{DPI}(U)_{i} / \operatorname{DPI}(E)_{i}$, for every individual $i$ in our dataset where $\operatorname{DPI}(\mathrm{U})=$ equivalised household

disposable income when the person is unemployed and $\mathrm{DPI}(\mathrm{E})=$ equivalised household disposable income when the person is employed; in both cases we equivalise household disposable income using the modified OECD scale ${ }^{7}$. We also decompose the NRR2 indicator to show which income sources play a larger role in providing resources in unemployment. For this purpose, we disaggregate household disposable income into seven components, which are calculated for each employed individual at the household level when the individual becomes unemployed. We then show what share of previous household disposable income is accounted for by each income source

Thus, more formally

$\operatorname{DPI}(U)_{i}=\sum_{k=1}^{7} I(U)_{k i}$, where $I(U)_{k}$ is one of: market incomes, public pensions, non means-tested benefits (including the unemployment benefit), means tested benefits (including social assistance), minus direct taxes, minus social insurance contributions paid by employees or minus social insurance contributions paid by the self-employed, all calculated when the individual is unemployed

$N R R 2_{k i}=I(U)_{k i} / \operatorname{DPI}(E)_{i}$

3) The level and change in the participation tax rate (PTR) which is a measure of work incentives at the extensive margin:

$\operatorname{PTR}_{i}=1-\frac{\operatorname{DPI}(E)_{i}-\operatorname{DPI}(U)_{i}}{E_{i}}$, where $\operatorname{DPI}(E)_{i}=$ household disposable income when the person $i$ is employed, $\operatorname{DPI}(U)_{i}$ is household disposable income when person $i$ is unemployed and $E_{i}=$ earnings of individual $i$. We decompose the PTR into seven income components in the same way we decompose the NRR2 indicator. More specifically, for each of six income sources: public pensions, non-means-tested benefits, means-tested benefits, direct taxes, social insurance contributions paid by the employees and social insurance contributions paid by the self-employed we calculate

$P T R_{k i}=\frac{I(E)_{k i}-I(U)_{k i}}{E_{i}}$, where $I_{k}$ is one of the six income components described above.

7. This scale gives a weight of 1 to the first adult, 0.5 to the other adults in the household and 0.3 to children (defined as individuals aged less than 14). 


\section{Impact of the unemployment insurance reform on the replacement rate}

16. As the replacement rate varies depending on unemployment duration and on earnings, the impact of the reform on the average replacement rate is analysed by quintile of individual earnings and broken down by month of receipt. Replacement rates by month are averaged across every quarter of benefit receipt.

17. The reform would result in increased NRR1s across all earnings quintiles: the level of the average annual replacement rate increases over the entire distribution of earnings from around $22 \%$ to around $44 \%$. This is due to the increase in the replacement rate of the additional part of the benefit, increased benefit ceilings and its increased duration. The effect is especially visible for the months 7-9 of receipt as one of the aims of the reform is to prolong the duration of the benefit (Figure 3).

18. The unemployment benefit is reduced over time to provide higher income stabilization during the initial months of unemployment and higher incentives to take up a new job thereafter. For instance, during the initial first three months, NRR1s after the reform reach around 75\% in the first three quintiles (previously around 55\%), while the replacement rates drop to around 66\% in the following three months (previously around $46 \%$ ).

19. The establishment of a ceiling for high earners results in a flat profile of replacement rates for this group. This implies that financial incentives to take a job for this group are high already starting from the first months of receiving unemployment benefits both in the current system and in the reform scenario. This is the case of quintiles 3-5 before the reform and quintiles 4-5 after the reform. Figure 3. NRR1s for unemployment benefits by earnings quintile and month of receipt before and after the
reform

Percent

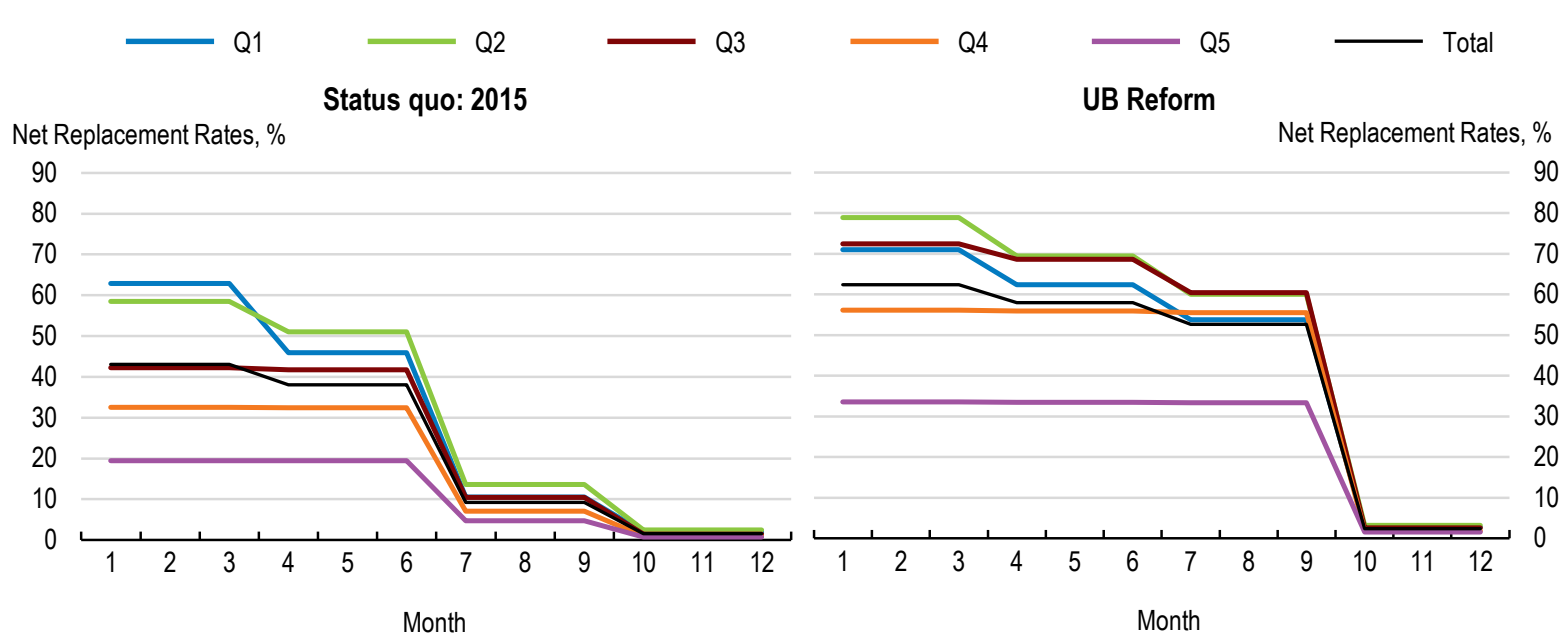


Table 3. Mean and cut point of net earnings' quintiles in EUR per month:

\begin{tabular}{l|l|l|l|l|l}
\hline $\begin{array}{l}\text { Source: Statistics Lithuania } \\
\text { - http://osp.stat.gov.lt/ } \\
\text { [accessed on 2015.11.09] }\end{array}$ & & & & & \\
Net earnings quintile: & 1 & 2 & 3 & 4 & 5 \\
\hline Mean & 289.3 & 481.0 & 668.8 & 900.4 & 1568.6 \\
Max & 381.9 & 575.6 & 771.0 & 1066.1 & 3789.5 \\
\hline
\end{tabular}

20. The replacement rates are higher in the lower income quintiles both before and after the reform. The replacement rate is lower for the higher income quintiles, but in relative terms the reform would imply a higher increase for this group (Figure 4). This results in a closer link between benefits and earnings after the reform. The average replacement rate after the reform and during the initial three months in receipt is around 55\% for the $4^{\text {th }}$ quintile (compared to around 33\% before the reform) and around $35 \%$ for the $5^{\text {th }}$ earnings quintile (compared to around $20 \%$ before the reform). The gap with previous earning for the highest quintiles would however remain substantial (at 45\%-65\%), and hence strong incentives for job search remain.

Figure 4. Average annual NRR1s for unemployment benefits by earnings quintile before/ after the reform and relative change

$\%$ of the previous earnings

Status quo: 2015

UB Replacement Rates, \%

60

50

40

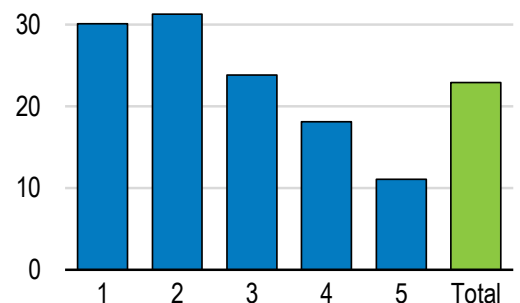

UB Reform

UB Replacement Rates, \%

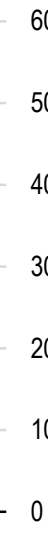

Relative change

Change in UB Replacement Rates, \%

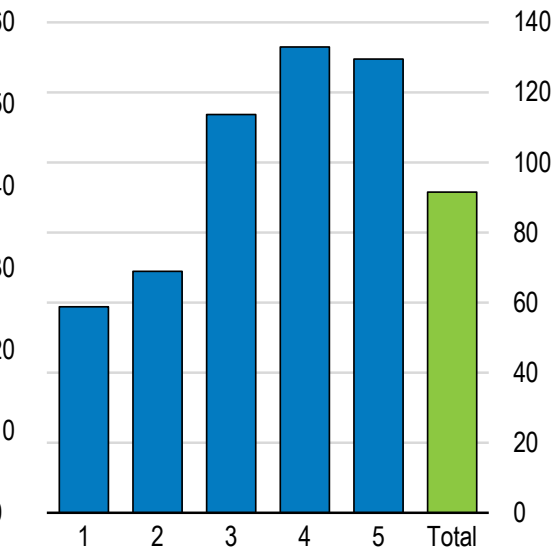

Impact of the unemployment insurance reform on the replacement rate at the household level

21. The impact of the reform at the household level, when taking into account the inter-connections between unemployment benefits and other elements of the social protection system (i.e. means-tested benefits, taxes, social insurance contributions) as well as the effects of earnings of other household members, are in line with previous results obtained at the individual level (Figure 5):

- The unemployment benefit makes up a higher share of previous disposable income after the reform for all quintiles (i.e. around $35 \%$ on average in the reform scenario compared to around $20 \%$ in the current system). This results in more generous total annual replacement rates (i.e. on average around $75 \%$ versus around $60 \%$ in the current system). 
- The declining pattern across the income distribution is less pronounced after the reform due to the increase in the unemployment benefit's ceilings: the annual average NNR2 in the top quintile stands at around 55\% after the reform versus around $40 \%$ in the current system. Within the context of the widely spread shadow economy in Lithuania this could potentially increase the motivation to participate in the unemployment social insurance system for those with high earnings.

- Compared to the replacement rate at the individual level (NRR1s), the replacement rate at the household level (NRR2s) increase less in relative terms at the top of the income distribution. This is because those at the top usually have more (market) income sources to rely on and thus can better insure themselves against unemployment shocks. For those living in the worse-off households, social insurance is more important for mitigating income shock and preventing poverty risk in case of unemployment

Figure 5. Total annual NRR2s by quintile of earnings before and after the reform

$\%$ of the total household disposable income

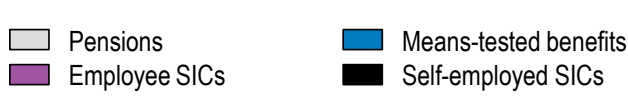

Status quo: 2015

Net Replacement Rates, \% 100

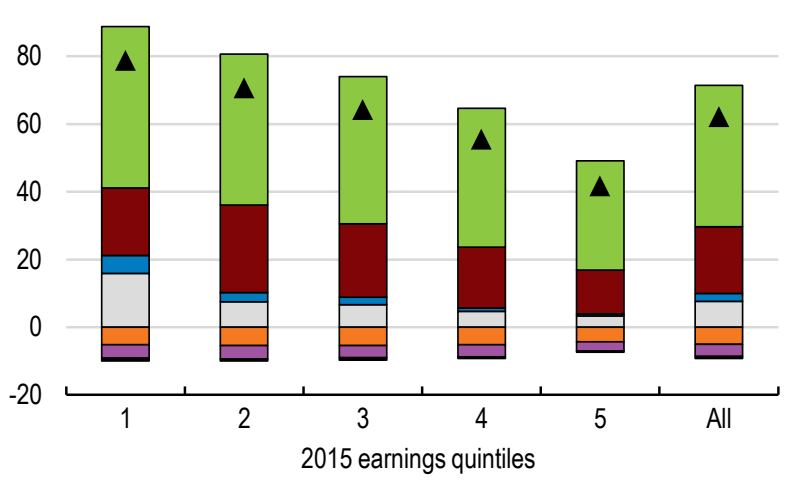

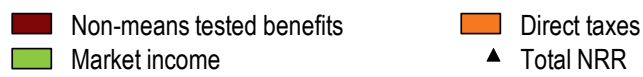

UB reform

Net Replacement Rates, \%

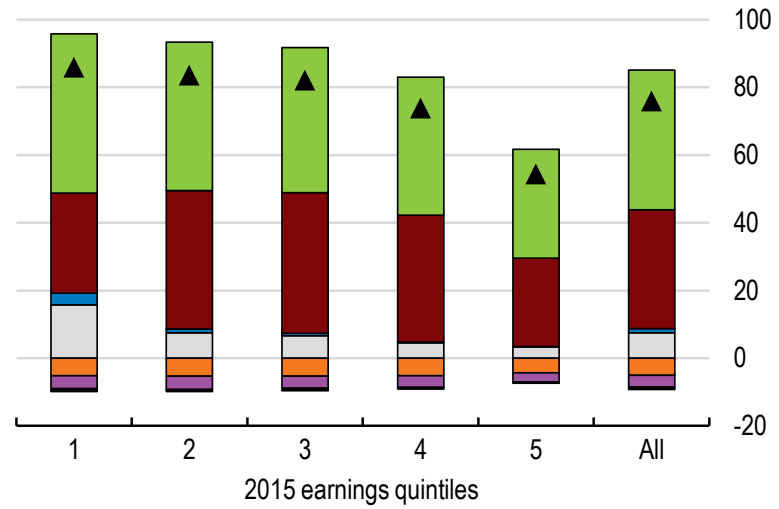

\section{Impact of the reform on the participation tax rate}

22. Financial incentives to take a job are measured by the participation tax rates (PTRs) which indicates the fraction of earnings taxed away through taxes, social insurance contributions and withdrawal of benefits if the unemployed person finds work with a salary level equal to earnings before unemployment. ${ }^{8}$ The financial disincentives to take a job is higher for those at the bottom of the income distribution and for those family types where the incidence of cash social assistance is higher (i.e. couples with many children and single parents). The PTR indicator reaches almost $80 \%$ for the first decile, twice the rate observed at the top, which comes mostly through the system of cash social assistance rather than

8. As previously the indicator is reported in average annual terms, i.e. averaging unemployment benefit receipt and other income components across a one-year period 
unemployment benefits. By contrast, the effects of the unemployment benefit and other income components are around equally distributed across deciles and family types (Figure 6, Panel A).

23. An increase in the PTRs is expected for all family types due to increased benefit generosity, higher ceilings and longer duration. The magnitude of an average increase in the PTRs is at around 16 ppts in the total population. The unemployment benefits reform increases the PTRs for those in the middle and upper part of the income distribution most, as these groups are those for which unemployment benefits increase most (Figure 6, Panel B).

24. The system of unemployment benefits interacts with the system of means-tested benefits: the increase in the generosity of the unemployment benefits will in part be counteracted by withdrawal of means-tested benefits for those in receipt of social assistance. This effect is stronger for lone parents, large families and for those at the bottom of the income distribution (Figure 6).

Figure 6. Average annual PTRs before and after the reform by earnings decile and by family type

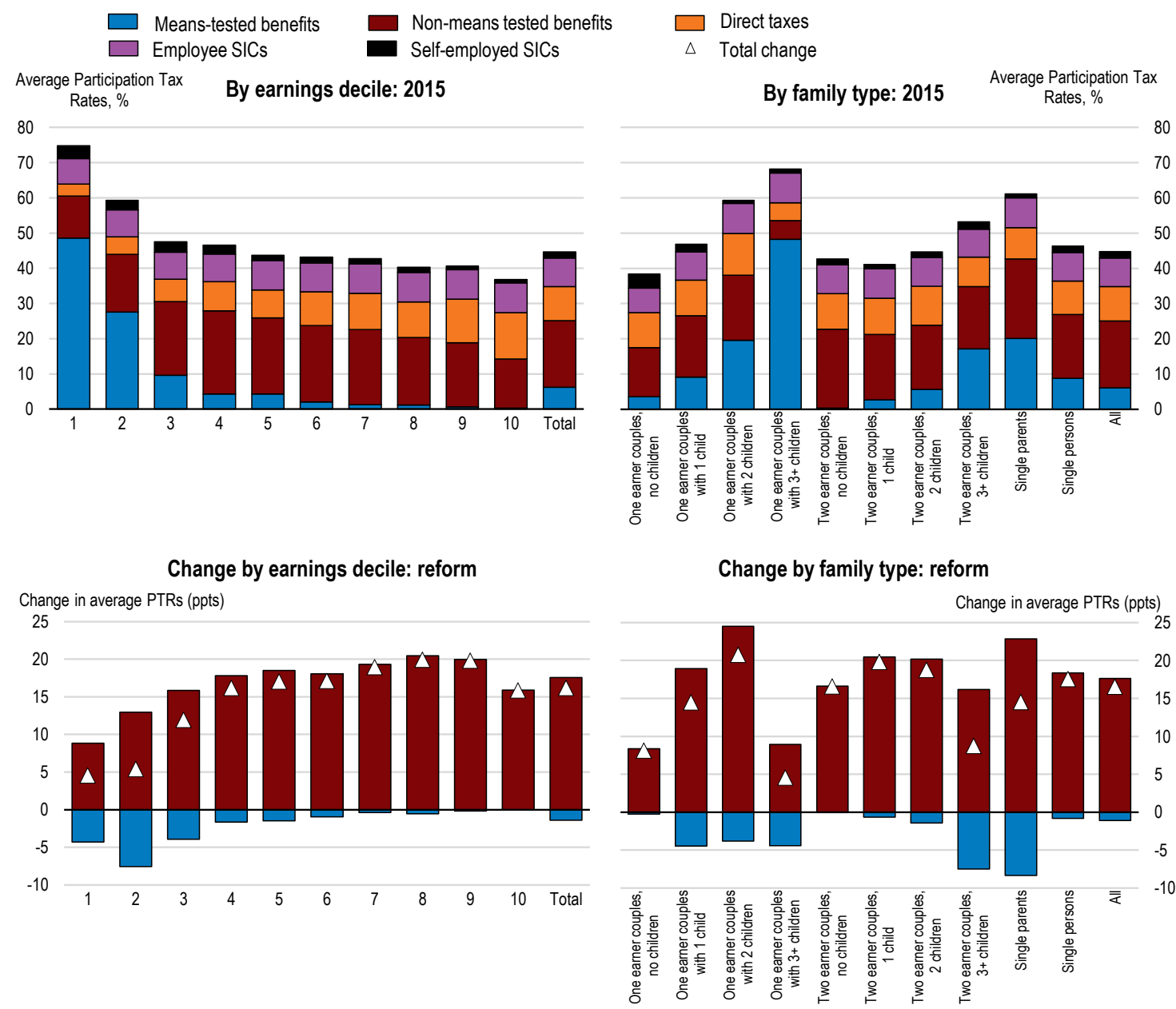

Note: family types I - for adult, i - for a child, earn- for earner. 


\section{Effect of the unemployment benefit reform on disposable income and inequality}

25. In addition to the work incentives indicators presented above, the distributional effects of the reforms are calculated. While the effects on the unemployment benefit replacement rates are the most pronounced among those with highest earnings (see Figure 4), those at the bottom of the income distribution benefit most from the reform relative to their total disposable income, i.e. relative to their income before the reform (Figure 7). In addition, the positive distributional effect is likely to be further strengthened due to the differential prevalence of the risk of unemployment across the income distribution.

26. As previously, individuals at the lowest end of the income distribution who would be eligible for unemployment benefit would potentially lose their entitlement to social assistance benefits (Figure 7). This would partly mitigate the positive effect of the reform, especially for the group of families with $3+$ children and single parents.

Figure 7. Change in the total household disposable income by income decile

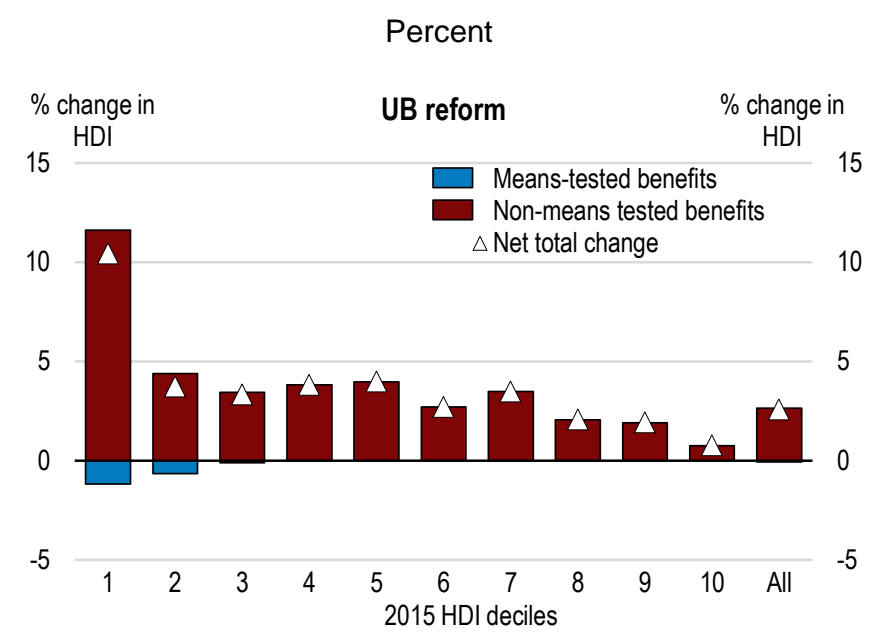

Reform scenarios of the social assistance scheme

\section{Characteristics of the current social assistance benefit system}

27. Social assistance is the main means-tested element of the Lithuanian system of cash social benefits. However, the adequacy of the system in providing for basic needs and reducing income poverty in Lithuania is insufficient despite a significant increase of the SSI just before the crisis (Latzutka 2014). The social assistance base amount (SSI) is currently set at 102 EUR, which only covers food expenses ${ }^{9}$. It made up only around $63 \%$ of the at-risk-of-poverty line at $40 \%$ of the median equivalized disposable income in $2013^{10}$ (2014 SILC). In addition, there is evidence that the design of the current system generates negative effects on work incentives at the bottom of the income distribution (Navicke \& Lazutka 2015). ${ }^{11}$

9. According to unpublished estimations by Lazutka et al. in scope of the European Reference Budgets Network: www.referencebudgets.eu.

10. According to estimations by Zabarauskaite (2008) if updated to 2013 by inflation, absolute poverty was at around 40\% of the median equivalized income in Lithuania, i.e. 160 EUR in 2013 (2014 SILC)

11. Another important point regarding benefit adequacy which is not discussed in this paper but worth to note is the absence of regular indexation rules of the SSI level which is adjusted on an ad-hoc basis (the last 
28. The social assistance benefit system was reformed in 2012 with a view to reduce expenditure and improve work incentives among recipients. Some of the measures implied a decline in benefits such as the reduction of social assistance benefits with time and the introduction of equivalence scales assuming economies of scales in household spending (in place of the per capita calculations applied before). On the other hand, the introduction of extra in-work payments for social assistance recipients who have been longterm unemployed and who found a job provides higher financial incentive to take a job without undermining benefit adequacy. However, this scheme has been used very little in Lithuania so far.

\section{Box 3. Social assistance benefit in Lithuania (as of December $1^{\text {st }} 2015$ )}

The social assistance benefit (socialiné pašalpa) acts as a top-up and a last resort income relief for those in need in Lithuania. It is granted to families or single persons if they pass established eligibility criteria, i.e. assets and income tests. The family unit for determining entitlement to social assistance consists of partners and their own dependent children. Dependent children are persons aged under 18 or under 24 if in full-time education or unemployed; they cannot be married, cohabiting with a partner, nor parents themselves.

The base for the estimation of social assistance is the amount of State Supported Income (SSI):

\begin{tabular}{cccc}
\hline & 2007 & 2008 & $2009-2015$ \\
\hline $\begin{array}{c}\text { State supported income (SSI), } \\
\text { EUR }\end{array}$ & 60 & 102 (since 2008.08.01) & 102 \\
\hline
\end{tabular}

Source: Based on the relevant version of Government of Lithuanian Republic Resolution „Dèl valstybès remiamų pajamų dydžio patvirtinimo".

Note: Exchange rate of 3.4528 applied for conversion of the SSI to EUR up to 2015, rounded up values.

The amount of the social assistance benefit is estimated in the following way:

$S A=(S S I-I / n)^{*} e q$,

where SSI - level of the State supported income, I - total income of the individual or family, $n$ - number of family members, eq - the sum of the equivalence scale applied for social assistance. The equivalence scale applied for determining social assistance benefits allows for the maximum social assistance amount to reach $100 \%$ of SSI only for a single adult or the first family member. The second family member is eligible for assistance at $80 \%$ of SSI, while third and subsequent members at $70 \%$ of SSI. Before the reform of social assistance in 2012 the maximum level of assistance for an individual / family member was at $90 \%$ of SSI.

This implies the following relation between assistance withdrawal and extra income:

$$
\begin{aligned}
& \Delta S A=\left(S S I * e q-I * \frac{e q}{n}\right)-\left(S S I * e q-\tilde{I} * \frac{e q}{n}\right), \\
& \Delta S A=\Delta I * \frac{e q}{n}
\end{aligned}
$$

Hence the withdrawal rate of social assistance is at $100 \%$ for single persons and close to that margin for other family types.

adjustment took place in 2008 ). The lack of automatic indexation leads to erosion of the real value of assistance through inflation. On the other hand, it makes the system vulnerable to ad-hoc increases in SSI towards the minimum wage, eroding the work incentives of beneficiaries. 
29. In this section, we simulate three reform scenarios aimed at further strengthening work incentives without eroding the social protection floor provided by the system of social assistance:

a. A first reform scenario consists of extending the current system of in-work payments for social assistance recipients who have been unemployed between 6-12 months (compared to at least 12 months in the current system).

b. The second reform is more ambitious as it aims at introducing earnings disregards for all benefit recipients (up to 102 EUR / 130 EUR). This would strengthen work incentives for all low-paid workers whatever their previous status and without limitation in the duration.

c. The third reform scenario aims at making the equivalence scale steeper in order to strengthen the financial incentives for large families to take a job. To maintain benefits adequacy the reform is combined with flat-rate supplements for children.

d. 30.To evaluate work incentives under our proposed social assistance reforms we calculate the financial impact of increasing labour supply at the extensive margin with the participation tax rate indicator and at the intensive margin with the marginal effective tax rates (METRs).

\section{Box 4. Measures of work incentives for social assistance recipients}

The level and change in the marginal effective tax rate (METR) are defined as:

$\operatorname{METR}_{i}=1-\frac{D P I(E 1)_{i}-D P I(E 0)_{i}}{E 1_{i}-E 0_{i}}$, where E0=current earnings, E1=increased earnings, $\mathrm{DPI}(\mathrm{E} 1)=$ household disposable income when the earnings of person $i$ are increased, $\mathrm{DPI}(\mathrm{E} 0)=$ current household disposable income. We decompose the METR into six income sources (public pensions, non-means-tested benefits, means-tested benefits, direct taxes, social insurance contributions paid by the employees and social insurance contributions paid by the self-employed) and we calculate

$M E T R_{k i}=\frac{I(E 1)_{k i}-I(E 0)_{k i}}{E 1_{i}-E 0_{i}}$, where $I_{k}$ is one of the six income components described above.

To calculate METRs, we simulate a $3 \%$ increase in earnings which is roughly equivalent to working an extra hour per week (intensive margin).

On an extensive margin we simulate an increase in earnings from their current level to the level of the monthly full-time minimum wage for social assistance recipients (METR2).

\section{First reform option: extending the in-work benefit scheme}

\section{Extending the in-work benefit scheme to a wider range of non-employed}

31. The first reform scenario of the social assistance benefit in Lithuania involves an extension of the current system of in-work payments to unemployed social assistance recipients upon finding a job. The inwork payments are extended to cover those who have been in receipt of cash social assistance between 6 to 12 months before finding a job. This could potentially increase incentives to find and take-up jobs for short term unemployed social assistance recipients, preventing them from becoming detached from the labour market. 
32. The current system allows the long-term unemployed social assistance recipients to keep 50\% of their previous assistance benefit amount for up to 6 months if they get into employment with a salary at above $3 / 4$ of the minimum monthly wage (MMW) and below the level of 2 MMW. However, the in-work payments are targeted at a selected group of recipients and for a limited time. As a result, the current system has limited scope (see Figure 8). The absolute number of beneficiaries receiving additional in-work payments (i.e. 2820 cases in 2014, 2383 cases in 2013) made up only around $2 \%$ of the total number of social assistance recipients and around $4 \%$ of all the long-term social assistance recipients while the associated total expenditure was less than $0.3 \%$ of the total expenditure on social assistance (Table 4 ).

33. At the same time it is worth noting that in the current system, $32 \%$ of social assistance recipients who found a job receive in-work benefits. This suggests that this scheme may potentially be effective at increasing work incentives but more could be done to ensure that the system reaches its full potential.

34. A potential explanation for the low take-up of in-work benefit may be related to the characteristic of the targeted population with comparatively low job prospects. Around half of recipients of social assistance are long-term recipients, receiving cash social assistance for a period of more than 12 months. These are the individuals targeted by the current in-work benefit scheme. They may encounter more difficulties to find work in the context of the still high unemployment levels in Lithuania as well as due to their detachment from the labour market. ${ }^{12}$ The remaining half of recipients were in receipt for a period up to one year, including $31.5 \%$ were in receipt for up to six months, and $18.3 \%$ of social assistance recipients were in receipt for a period of between six to twelve months. Importantly, the latter groups are likely closer to the labor market and could hence be more sensitive to in-work benefits.

35. Another potential explanation for the low take up of in-work benefit is the limited duration of the benefits as it is only granted for up to 6 months and is withdrawn thereafter. Once the in-work payment is expired its amount is included into the income test for social assistance. Hence social assistance payments are likely to be discontinued. This may have a negative effect on the incentives to take up a temporary or otherwise unstable or little paid job and could be another area of reform. Several countries have for instance implemented unlimited in-work benefits (Immervoll and Pearson, 2009).

Figure 8. Number of recipients and total expenditure on social assistance in-work payments,

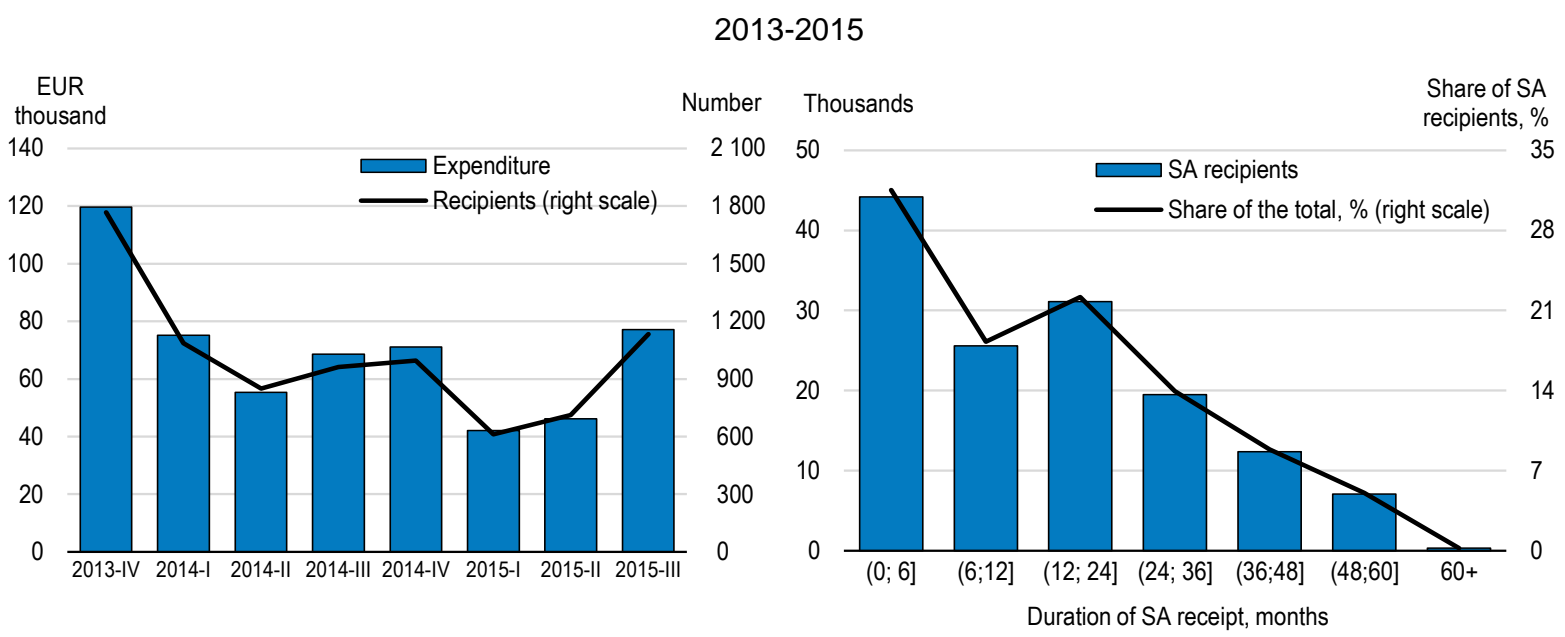

Source: SOCMIN

12. Another potential explanation is that the extra payment is relatively new and potential beneficiaries may not be aware of it. 
Table 4. Recipients and expenditure on cash social assistance and additional payments for long-term SA recipients on finding a job, 2013-2014

\begin{tabular}{ccc|cc|cc}
\hline \multicolumn{2}{c|}{ A. Social assistance } & \multicolumn{2}{c|}{$\begin{array}{c}\text { B. Additional payments } \\
\text { on finding a job }\end{array}$} & \multicolumn{2}{c}{ Share in \% (B/A) } \\
\hline $\mathbf{2 0 1 3}$ & recipients & $\begin{array}{c}\text { expenditure, } \\
\text { thous. EUR }\end{array}$ & recipients & $\begin{array}{c}\text { expenditure, } \\
\text { thous. EUR }\end{array}$ & recipients & expenditure \\
$\mathbf{2 0 1 4}$ & 190009 & 147174.1 & 2383 & 188.2 & 1.25 & 0.13 \\
\hline
\end{tabular}

Source: SOCMIN. Notes: Average annual numbers of recipients.

\section{Assumptions for an extension of the in-work benefit scenario}

36. To implement the scenario on the extension of in-work benefits we need to establish who among social assistance recipients is entitled to the in-work payments and who is potentially eligible under the new scheme, depending on the duration of non-employment. However, the length of social assistance receipt in the EU-SILC data is not observable. To model social assistance recipients' eligibility for additional in-work payments, we make the following assumptions:

- Based on administrative statistics (see Table 5) we identify the fraction of social assistance recipients who were unemployed for more than 12 months among all social assistance recipients who found a job (2820 out of 8920 , i.e. $32 \%$ of newly employed who were social assistance recipients).

- The newly eligible population after the reform is equal to the share of those in receipt of social assistance for 6-12 month in the total population of short-term assistance recipients (i.e. 38\%).

- Assuming equal employment rates among all the short term social assistance recipients (0-12 months) we pick randomly the newly eligible recipients of in-work benefits among the remaining newly employed individuals who were previously recipients of social assistance.

- The total share of the newly employed who would receive in-work payments after the reform is hence found to be equal to around $58 \%$ of newly employed social assistance recipients compared to $32 \%$ in the current system.

Table 5. Recipients of cash social assistance and additional payments for long-term recipients on finding a job, 2014

\begin{tabular}{lc}
\hline & 2014 \\
\hline A. Additional recipients of SA payments on employment & 2820 \\
B. SA recipients who found a job & 8920 \\
C. Long-term SA recipients registered at the Labour Exchange & 26163 \\
D. SA recipients registered at the Labour Exchange & 46447 \\
E. Long-term SA recipients (12+ months) & 70359 \\
F. Short-term SA recipients (6; 12 months] & 25584 \\
G. Short-term SA recipients (0; 6 months] & 44171 \\
F. SA recipients & 140114 \\
\hline
\end{tabular}

Source: authors' calculations based on statistics provided on request by SOCMIN 
37. While a reform along those lines is aimed at increasing incentives to take jobs and hence would likely increase the number of social assistance recipients who find a job, we assume no behavioral changes in our simulations. This likely results in an underestimation of the potential impact of the reform. In addition, better employment prospects in Lithuania would also contribute to a higher take up of in-work benefits. Since EUROMOD does not capture the dynamic effects of the reform, which are difficult to predict, the effects demonstrated below should be interpreted as lower bound estimates.

\section{Impact of earnings on work incentives}

38. The new design of the in-work payments increases the social assistance amount for which a newly employed individual was eligible before employment by half (i.e. by max 51 EUR). For the individuals at the lowest level of earnings this would contribute to an increase in income by around $25 \%$, while for those social assistance recipients at the highest earnings' level - by around 10\%. Families and single parents with children gain less relative to their previous level of income compared to single individuals.

Figure 9. Change in amounts of social assistance with growth in net earnings for singles and couples previously unemployed for 6-12 months

Reform A
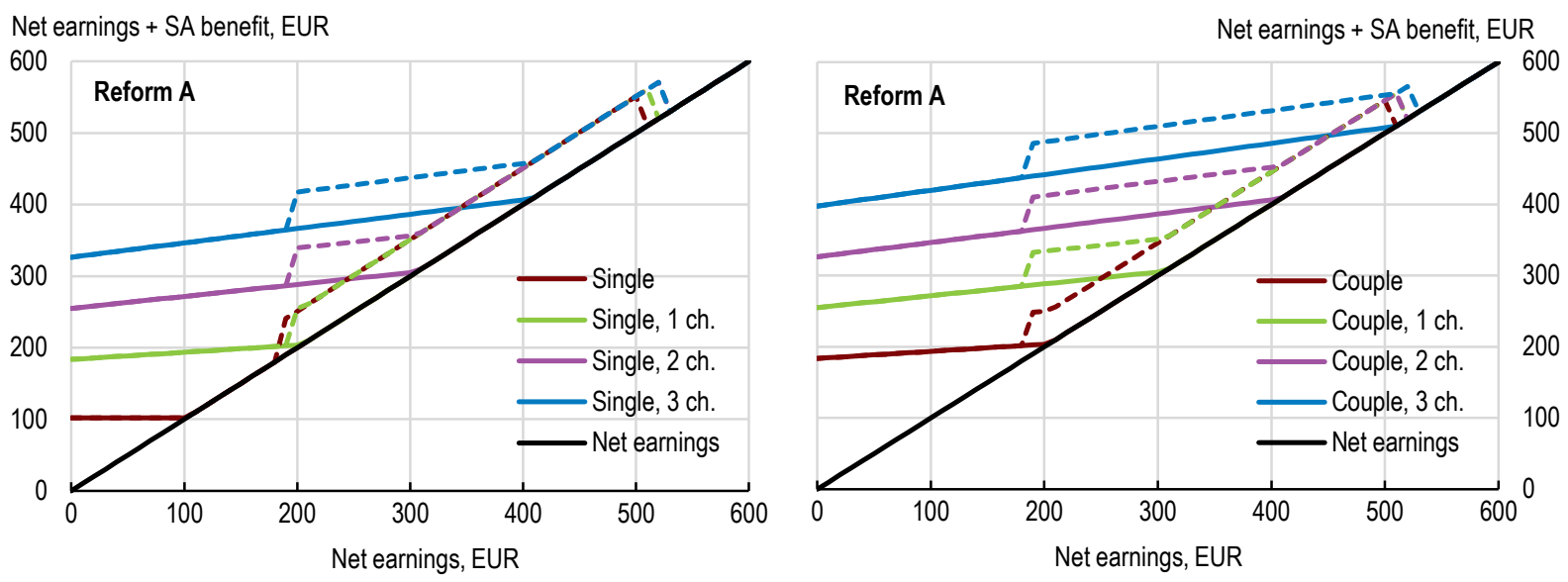

Note: Income including social assistance in the reformed system - dashed line; in the current system- solid line. All family members assumed to qualify for social assistance subject to income test; for couples one earner assumed.

39. The in-work benefit as currently designed implies a non-linearity in the social assistance system. The non-linearity is reflected in the increase in income once the person becomes eligible for in-work payments and abrupt decrease once payments expire. Only those who get into employment at a level of $3 / 4$ of the minimum salary and a maximum of 2 minimum salaries are eligible for receipt of the in work benefit. For some (e.g. single individuals) this level of earnings is well above the maximum social assistance threshold of 102 EUR. Others (e.g. single parents, couples) may become eligible while still in receipt of social assistance.

40. The extension of the in-work benefit to those unemployed in receipt of social assistance for 6-12 months brings only a marginal change to the PTRs in the total Lithuanian population, and the effect is concentrated in the lowest income decile (Figure 10). This low average impact is mostly due to the limited number of beneficiaries of the reform. As discussed above, the total number of in-work benefit recipients is only a small fraction of social assistance recipients (around 2\%). Hence, even as the number of in-work benefit recipients almost doubles in our scenario, the overall impact remains marginal. Still, incentives to 
take-up jobs for potential recipients of in-work payments are substantial. As mentioned above in-work payments may contribute up to around $25 \%$ increase in income for eligible social assistance recipients.

Figure 10. Average change in PTR in the total population,

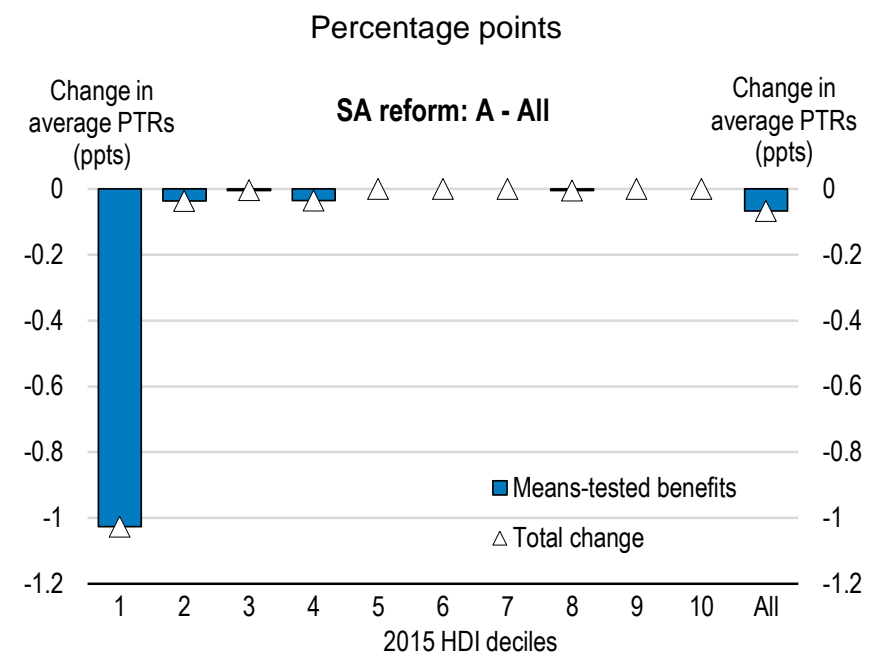

Impact on disposable income

41. In line with previous results, the average change of disposable income across the total Lithuanian population is marginal. The main effect is concentrated in the lowest income decile. The overall low impact is related to the methodology (the hypothesis of no behavioral change), but also to the fact that the population targeted by the reform is quite narrow (social assistance recipients unemployed for a period between 6 and 12 months). To obtain a more substantial and long-term impact on poverty and work incentives, a more substantial reform covering a larger population of poor is needed.

Figure 11. Change in the household disposable income by income deciles

Percent

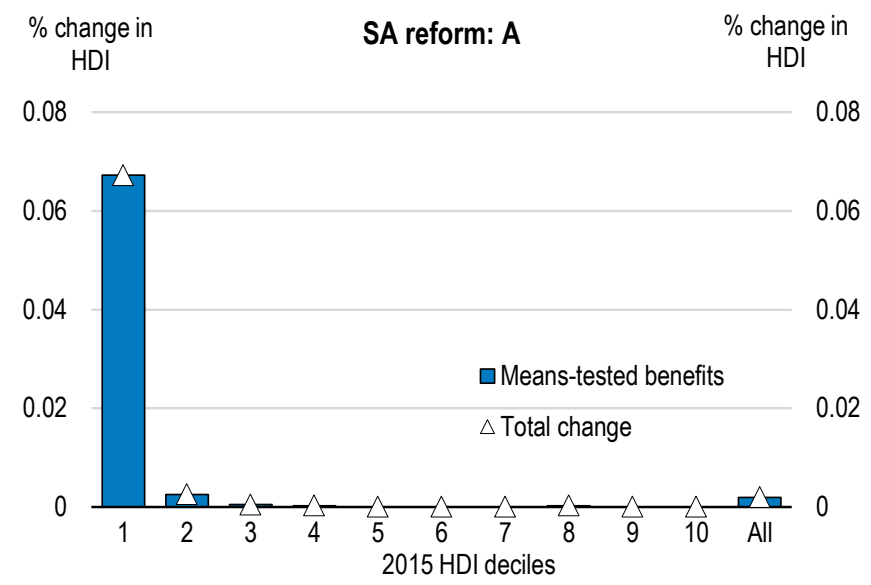




\section{Second reform scenario: introducing income disregards}

\section{Providing wider financial incentives to working poor}

42. Another direction for reform is to implement income disregards. This would extend the maximum level of earnings at which singles and couples are eligible for social assistance by not taking into account a portion of the recipient's earnings when establishing eligibility to social assistance. Similar income disregards are implemented in social assistance programs in Finland (at 20\% rate), Luxemburg (30\% exemption), Portugal ( $20 \%$ exemption), Slovakia (25\% exemption); deductions from earned income can also be made e.g. in Germany, other countries disregard certain types of income, such as child or family allowances (e.g. Estonia) (MISSOC 2015).

43. This scheme differs from in-work benefits as currently implemented in Lithuania in important ways. Whereas receipt of in-work benefits usually requires recipients to be newly employed at a minimum number of hours, earnings disregards simply reduce the withdrawal rate of social assistance when earnings increase. Those benefits make low pay jobs more attractive and can also encourage benefits recipients to work even for a limited number of hours due to a lower rate of social assistance withdrawal. Compared to the previous scenario, such a reform would benefit social assistance recipients who are already in work (and have not experienced any recent unemployment spell) and those in receipt for less than six months. The introduction of earnings disregard makes the income test for social assistance less strict and will only affect eligibility for those legally in work. For those without earnings the eligibility for social assistance will not change (as only earnings are disregarded; the treatment of other types of income remains the same). It is also worth noting that, income disregards may lower the incentive to hide earned income and could potentially make working in the formal sector more attractive. On the other hand, the current high share of informal work-related income may jeopardize the practical implementation of this scenario. ${ }^{13}$

\section{Main assumptions}

44. We consider two possible reforms (B1 and B2): in both cases $30 \%$ of net earnings are disregarded when applying the income test. In reform B1, we cap the level of the disregard at 102 EUR (the level of SSI) per earner. In reform scenario B2 we cap the maximum level of the disregard at a higher level of 130 EUR per earner. As the cap of the income disregard is reached any extra earned income is withdrawn at the same pace as before the reform (i.e. flattening line as visible in Figure 12). By design, the effects of the two reforms (B1 and B2) on work incentives are similar, while B1 (with a lower threshold on the maximum disregard) is less favorable for those with more dependent family members. In reform B2, families with children can keep a fraction of their earnings up to a higher threshold, i.e. adding up to a maximum of 130EUR compared to a lower threshold of 102EUR in reform B1.

\section{Impact on income and on work incentives}

45. The reform improves possibilities to combine earnings with social assistance recipients for all family types from the first additionally earned Euro. This results in higher levels of disposable income due to a lower withdrawal rate of social assistance. By contrast, increases in earned income for current social assistance recipients have only marginal effect on their disposable income.

46. Under the earnings disregard capped at 102EUR (B1) the level of net earnings at which individuals or families are eligible for assistance increases to around 130 EUR for singles without

13. According to a European Survey, $6 \%$ of dependent employees declared receiving informal payment in 2014, which above the European average at $3 \%$ but also 5 percentage point less than in 2007 (Eurobarometer, 2015). 
children, up to 500 EUR for singles with three children, 290 EUR for one-earner couples without children and up to 600 EUR for one-earner couples with three children. The maximum levels of net earnings at which individuals or families are eligible for social assistance are higher in the second scenario (B2) as a higher cap on the earnings disregard is applied.

\section{Figure 12. Change in amounts of social assistance with growth in net earnings for singles and couples}

Reform B1 \& B2
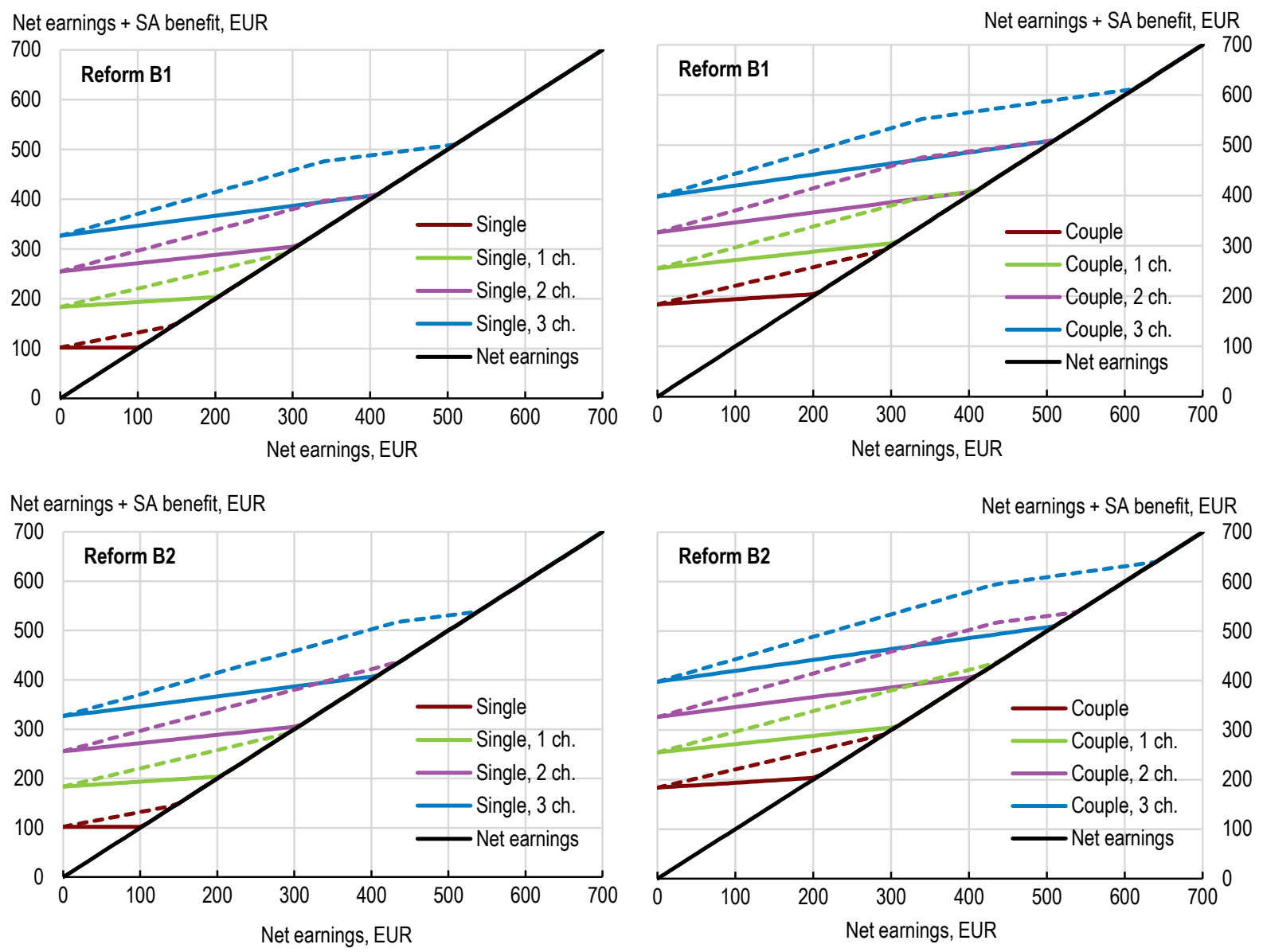

Note: Income including cash social assistance in the reformed system - dashed line; in the current system-solid line. All family members assumed to qualify for social assistance subject to income test; for couples one earner assumed.

47. While the reform scenario extending in-work benefits (A) potentially has an effect on the work incentives at the extensive margin (incentives to get a job), the introduction of the income disregards would also affect work incentives at an intensive margin (incentives to increase working efforts). Hence we use the indicators of the marginal effective tax rates (METR) for further analysis.

48. Financial incentives to increase labour supply among the population at the bottom of the distribution and among the social assistance recipients are comparatively low in the current system (Figure 13). This is due to the negative effect of the means-tested benefits, cash social assistance in particular. Splitting by family type the total METR is at or above $80 \%$ for all the identified family types who receive social assistance. This is especially true for single individuals and couples with no dependents as the withdrawal of benefit with earned income is lower as the family size increases due to use of equivalence scales (See Box 3 and Annex 1 for details). 
Figure 13. METR among those with positive employment income and among social assistance recipients, current situation

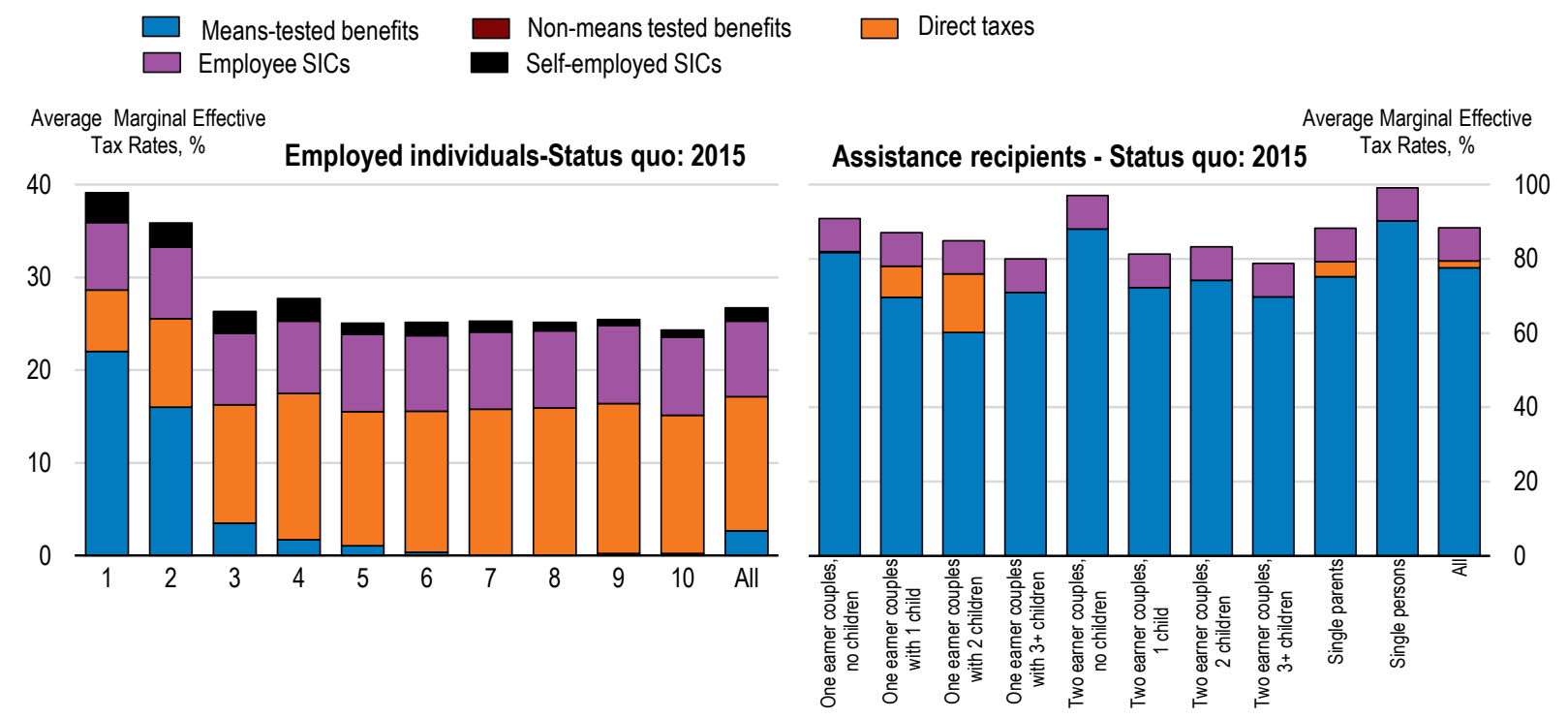

Note: family types I - for adult, $\mathrm{i}$ - for a child, earn- for earner.

49. The reform would result on average in around 25 p.p. decrease in the marginal effective tax rates among the current social assistance recipients (Figure 14). ${ }^{14}$ The effect is evenly distributed among the different family types and is more pronounced among singles and two-earner couples. For other family types the effect is slightly lower as even in the current system the withdrawal rate of social assistance is below 100\% due to the application of the equivalence scales (see Box 3 and Annex 1 for details). The higher ceiling of the disregard in the reform scenario B2 does not seem to have a significant effect compared to B1 scenario.

50. The METR would decrease for those already eligible and in receipt of social assistance in the current system (Figure 14). However, there will be a spill-over effect on those who are currently not eligible for social assistance, but become eligible under the less strict income test. As a result, families higher up in the income distribution can experience an increase of their METRs (Figure 15). The total effect reaches up to 6 ppts for the third decile. As a result, the reform might overall lead to an increase of the average level of METR in the total population, but the average impact is moderate: less than $1 \mathrm{ppts}^{15}$.

14. METRs are calculated assuming a 3\% increase in earnings, roughly corresponding to the working one more hour per week. In addition, METR were calculated when earnings are increased from their current level to the level of the monthly full-time minimum wage for social assistance recipients. Results are very similar. See Annex 2;

15. The average increase in the METR experienced by the whole population, and especially by the second and third income decile do not offset the gains observed for lower deciles, and especially social assistance recipients. 
Figure 14. Change in the marginal effective tax rates among social assistance recipients by family type

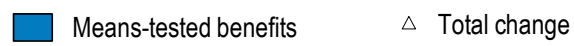

SA Reform: B1 - SA recipients

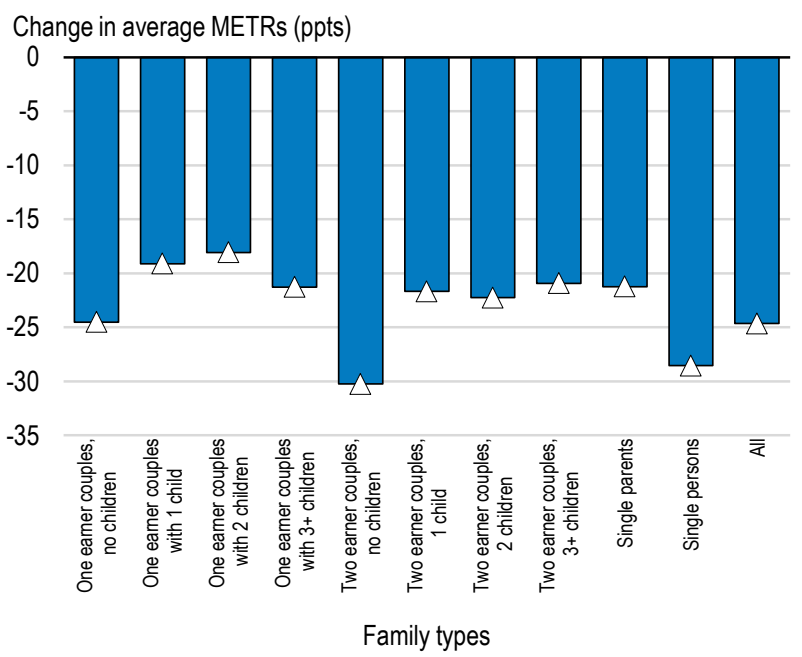

SA Reform: B2 - SA recipients

Change in average METRs (ppts)
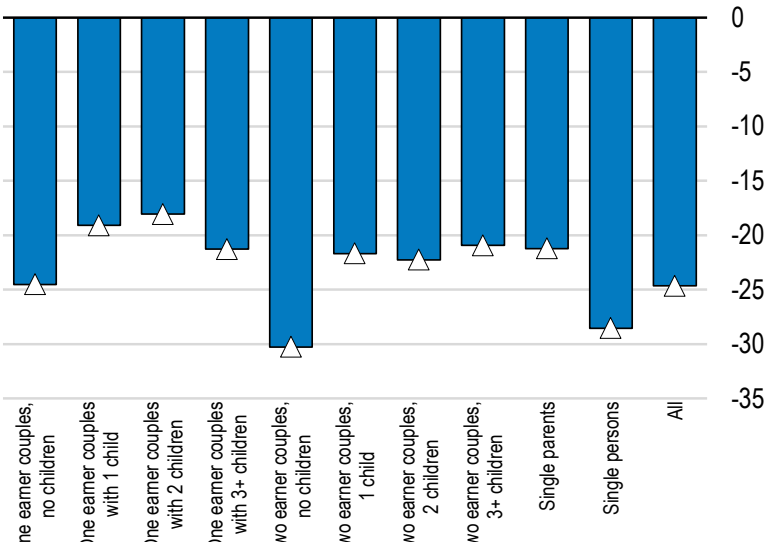

Family types

Note: family types: I - for adult, $\mathrm{i}$ - for a child, earn- for earner.

Figure 15. Change in the marginal effective tax rates by income decile

Means-tested benefits

SA Reform: B1 - Al

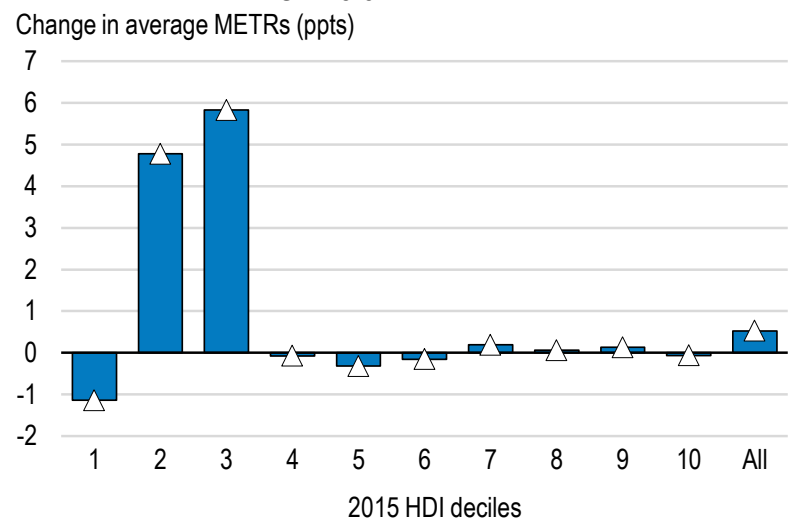

$\triangle$ Total change

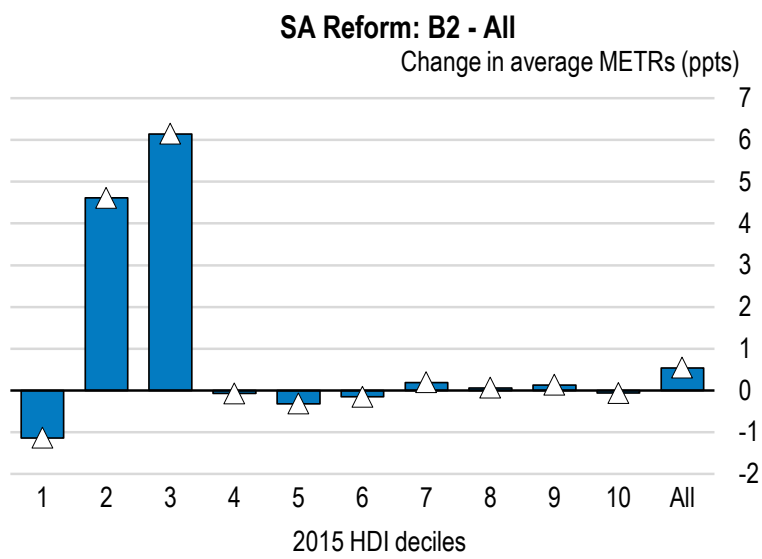

Effects of the reform scenarios on household disposable income

51. In both scenarios the household disposable income increases by around $3 \%$ on average in the lowest income decile. The two reform scenarios have similar effects. The introduction of earnings disregard would only support the working poor, while those without earnings won't be affected. Hence this effect can be interpreted as a lower bound (i.e. before any behavioral reaction to the reform occurs). Individuals at the bottom of the income distribution benefit more from the introduction of the income disregards but the increase in household disposable income extends towards families in the third income decile. This is due to the fact that poor families eligible for social assistance can live in relatively well-off households (as social assistance eligibility is determined at the family level, not the household level in 
Lithuania). Working parents with 3 and more children benefit most as they can use higher amounts of income disregards before exceeding the income test of social assistance scheme.

Figure 16. Changes in the eq. household disposable income due to reform by deciles of household disposable income and family type

Means-tested benefits $\quad \Delta$ Net total change

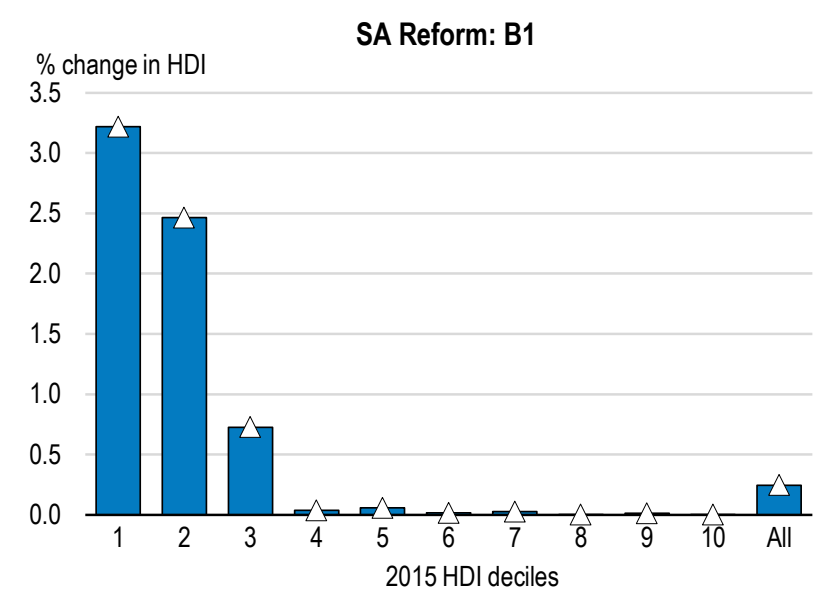

SA Reform: B1

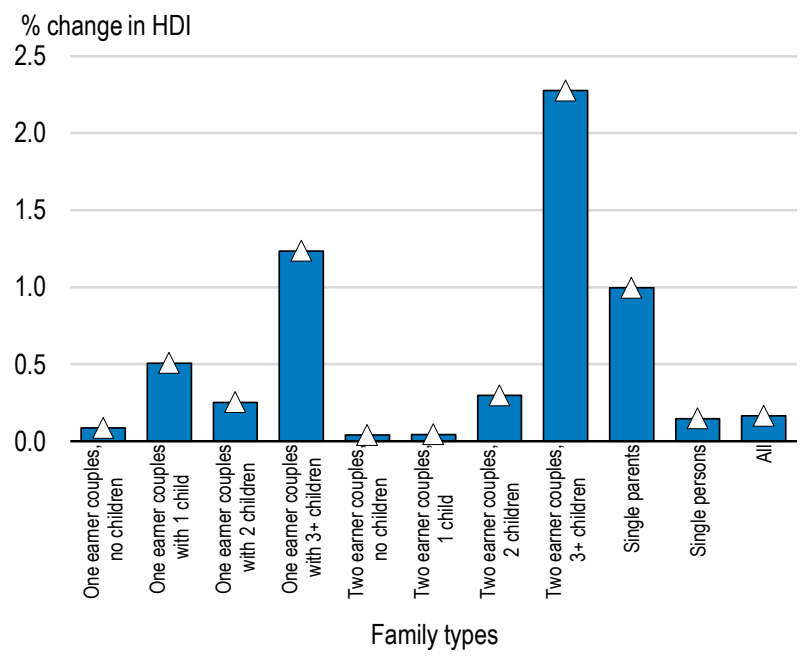

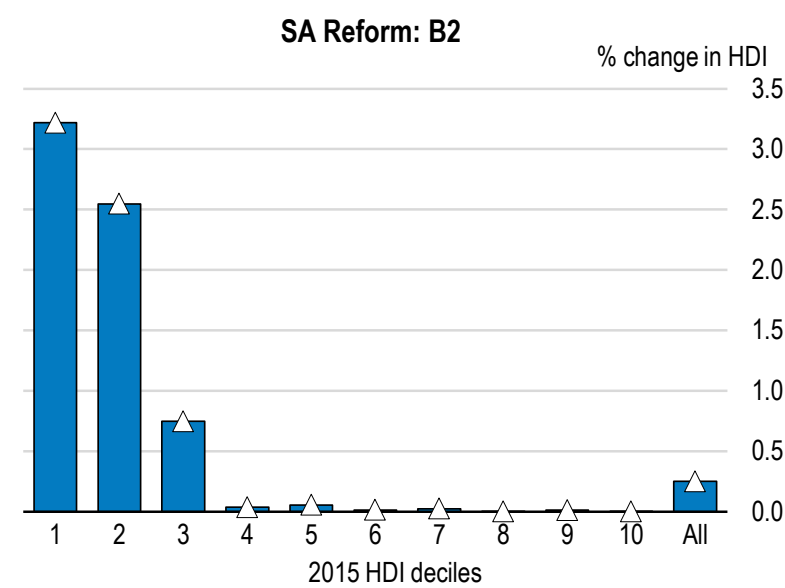

SA Reform: B2

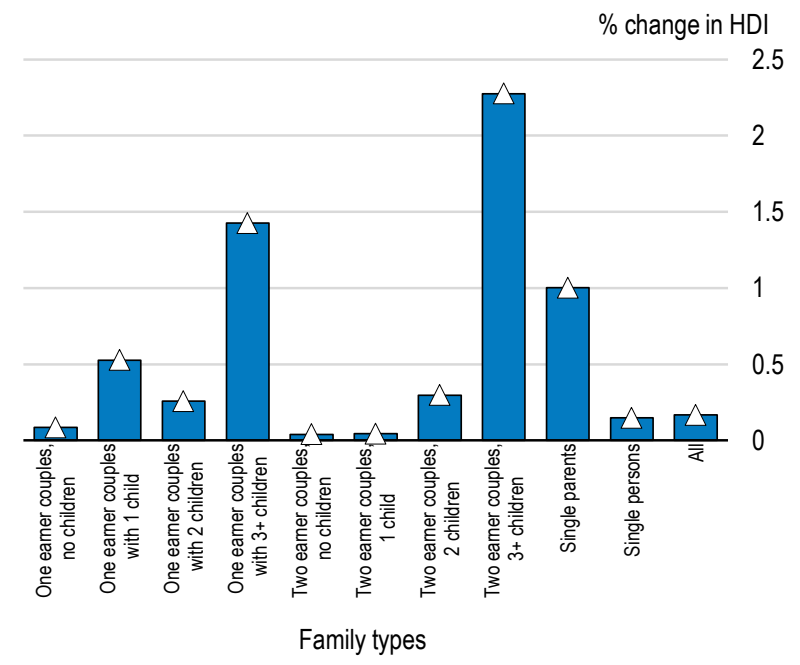

\section{Third reform scenario: re-designing support for large families}

52. Financial incentives to take a job depend strongly on the family size in Lithuania due to the comparatively flat equivalence scales for family members (see Box 3 ). The support for single individuals is for instance on average at $23 \%$ of median income while support for a married couple with two children reaches up to $42 \%$ of median income. As a result, moving from unemployment or inactivity to a job at twothird the average wage could generate a loss up to $83 \%$ of their additional income for the family while this loss is only $50 \%$ for singles (OECD, 2016). On the one hand, the current scheme provides only weak financial work incentives for large families. On the other hand, the current SSI level is inadequate for supporting single individuals. The third reform scenario is hence designed to tackle high effective taxation for large families while keeping an adequate support and to increase the support to singles (Figure 14 and $16)$. 


\section{Main assumptions}

53. While the generous equivalence may reduce financial incentives to take a job, the low base of social assistance support complicates any effort to make it steeper without taking the risk to expose social assistance recipients to higher poverty risk. In this third reform scenario, we hence combined steeper equivalence scale with flat rate supplements for children which would not jeopardize work incentives as they are not withdrawn in case the recipient takes a job as long as he is entitled to social assistance benefits. A similar structure of the general assistance amount plus supplement for families with children has been implemented e.g. in Estonia (MISSOC 2015). The third proposed reform scenarios have the following characteristics:

- We assume an increase of the level of SSI by around 30\% (to 130EUR) ${ }^{16}$. The level of SSI for a single person with one child would still be substantially below the level of net monthly minimum wage, i.e. increasing from $36 \%$ in the current system to $46 \%{ }^{17}$ (See Table 7).

- We replace the existing equivalence scale (see Annex 1) with two alternative steeper scales. In the literature these are commonly referred to as an original and modified OECD equivalence scales (see e.g. OECD 2013). The scales account for economies of scale in the cost of living and recognize the higher spending needs of adolescents (aged 14 or older) compared to younger children ${ }^{18}$.

- To compensate the negative effect of the he steeper equivalence scale for large families, we include a flat rate supplement for children modeled as part of social assistance ${ }^{19}$. Hence the flat rate supplement is received at its full rate as long as the family is entitled to social assistance. ${ }^{20}$

Table 6. Third scenario: main assumptions

\begin{tabular}{l|l|l|l}
\hline & \multicolumn{1}{|c|}{ Current system } & \multicolumn{1}{|c}{ Reform scenario C1 } & Reform scenario C2 \\
\hline SSI & 102 & 130 & 130 \\
\hline Equivalence scale & $1 ; 0.9 ; 0.7$ & $1 ; 0.7 ; 0.5$ & $1 ; 0.5 ; 0.3$ \\
\hline Children supplement & No & $\begin{array}{l}\text { 20 euros (lump sum, for lone } \\
\text { parents and families with 3+ } \\
\text { children) }\end{array}$ & 30 euros per child \\
\hline
\end{tabular}

16. SSI is used for other instruments of the Lithuanian system of social benefits - e.g. for unemployment benefit, child benefits. The reform only implies an increase in SSI level for assistance benefits

17. This ratio is expected to be lower once taking into account the increase in the MMA and tax allowances as planned for 2016.

18. While the OECD currently advocates for using the scale equal to square root of the household size, we use the so-called original and modified OECD scales. These scales are widely used and known in the Lithuanian and EU context. The modified OECD scale is applied for estimation of the official at-risk-ofpoverty rates by Eurostat and in Lithuania.

19. An alternative is to pay it through the child benefit scheme.

20. Supplement can be lower if the child benefits are excluded from the income text of social assistance as is currently the case in Lithuania. 
ECO/WKP(2016)34

Table 7. State supported income (SSI) as \% of the median eq. household disposable income (HDI) and monthly minimums salary (MMS)

\begin{tabular}{|c|c|c|c|}
\hline per month, EUR & 2014 & 2015 & Reform: $\mathrm{C} 1 \& \mathrm{C} 2$ \\
\hline SSI & 101.4 & 102 & 130 \\
\hline Net MMS (single, one child), (I) & 254 & 280 & 280 \\
\hline 40\% median HDI (II) & 160.8 & $\mathrm{n} / \mathrm{a}$ & 160.8 \\
\hline $50 \%$ median HDI (III) & 201.0 & $\mathrm{n} / \mathrm{a}$ & 201.0 \\
\hline SSI/minimum wage & $40 \%$ & $36 \%$ & $46 \%$ \\
\hline SSI/40\% of median HDI & $63 \%$ & $n / a$ & $81 \%$ \\
\hline SSI/ $50 \%$ of median $H D I$ & $50 \%$ & $n / a$ & $65 \%$ \\
\hline
\end{tabular}

Note: median equivalized household disposable incomes (HDI) based on EU-SILC estimates lagged by one year to correspond to the income reference period.

Source: SSI based on the relevant version of the Resolution of the Government of Lithuanian Republic "Dèl valstybès remiamy pajamų dydžio patvirtinimo"; Eurostat for median income; authors' calculations.

\section{Impact on income and work incentives}

54. The proposed combination of a higher SSI, steeper equivalence scale and supplements for children ensures that none of the family types is worse off after the reform. In both scenarios assistance levels increase for single persons due to an increase in the SSI not depending on their working status. For other family types assistance levels only increase for those with positive earnings as the increase in the level of SSI is offset by steeper scale.

55. The reform introduces a non-linearity of the social assistance system caused by the flat-rate child supplement. When the income level of social assistance recipients crosses the income test child supplements are withdrawn altogether. In reform $\mathrm{C}$, the non-linearity due to withdrawal of child supplements is small (amounts to max 20EUR), but the positive impact on work incentives is also lower. In reform $\mathrm{C} 2$, where a steeper equivalence scale is associated with higher child supplements, the non linearity is more abrupt, but a higher fraction of social assistance can be kept with the growth in earnings. ${ }^{21}$

21. The negative effect of the non-linearity in the system after $\mathrm{C} 2$ reform may be overcome by integrating the supplement for children into the system of child benefits, rather than paying it as a social assistance top-up. As currently the income test level for receipt of the child benefits is substantially higher compared to the system of social assistance (i.e. 1.5 SSI per family member), the withdrawal of child benefit would appear at a higher income level and in relative terms would constitute a smaller share of family's income. 


\title{
Figure 17. Change in amounts of social assistance with growth in net earnings for singles and couples
}

\author{
Reform C1 \& C2
}
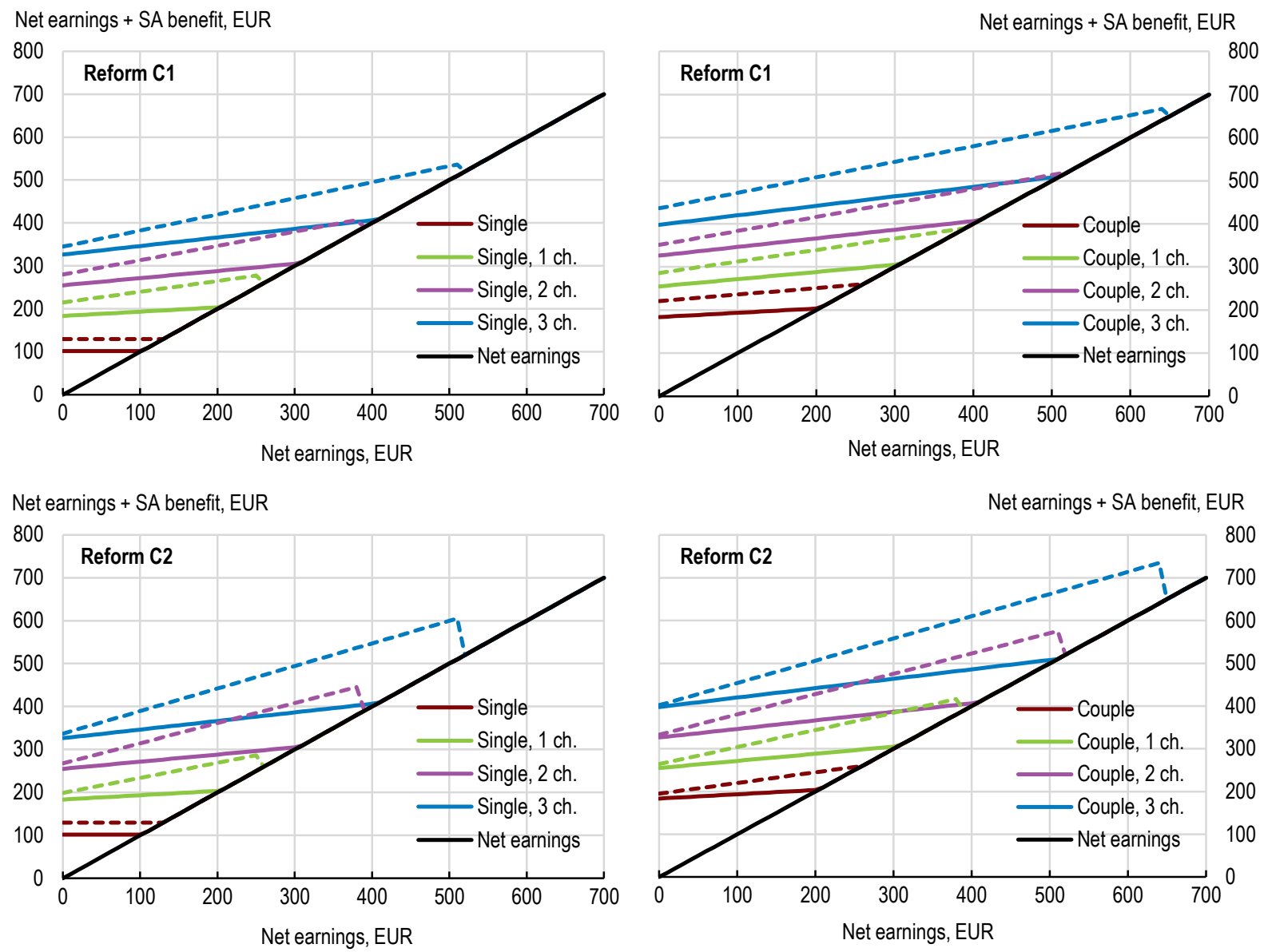

56. The introduction of the steeper equivalence scales improves work incentives and decreases METRs across all family types. Compared to the previous scenario with an income disregard this effect is stronger, particularly for families with children. This is because a lower withdrawal rate of social assistance is applied as the number of children increases. The withdrawal rate of social assistance is equal to $e q / n$, where $e q$ is the sum of the applied equivalence scale for the family and $n$ is the number of family members (see equation 3 in Box 3). As a result, the potential effect on the METR of families with children is about twice higher for the $\mathrm{C} 2$ compared to the scenario $\mathrm{C} 1$. By contrast, the METR of individuals without children are not significantly affected. ${ }^{22}$

57. Similarly to previous reform scenarios (B1 and B2), two counteracting effects can be identified: on the one hand, METR decrease for those eligible and in receipt of social assistance; on the other hand, there is a spill-over effect on families higher up in the income distribution who are currently not eligible for social assistance, but become eligible as the SSI level is increased. The reform scenario with a steeper equivalence scale $(\mathrm{C} 2)$ has a more profound effect higher up in the income distribution (i.e. in the $3^{\text {rd }}$ decile).

22. The effect of such reform can even be negative for single. According to addition simulations at the extensive margin, the change in METR when taking a job at the minimum wage could increase for single. See Annex 2. 
Figure 18. Change in the marginal effective tax rates

Means-tested benefits

SA Reform: C1 - SA recipients

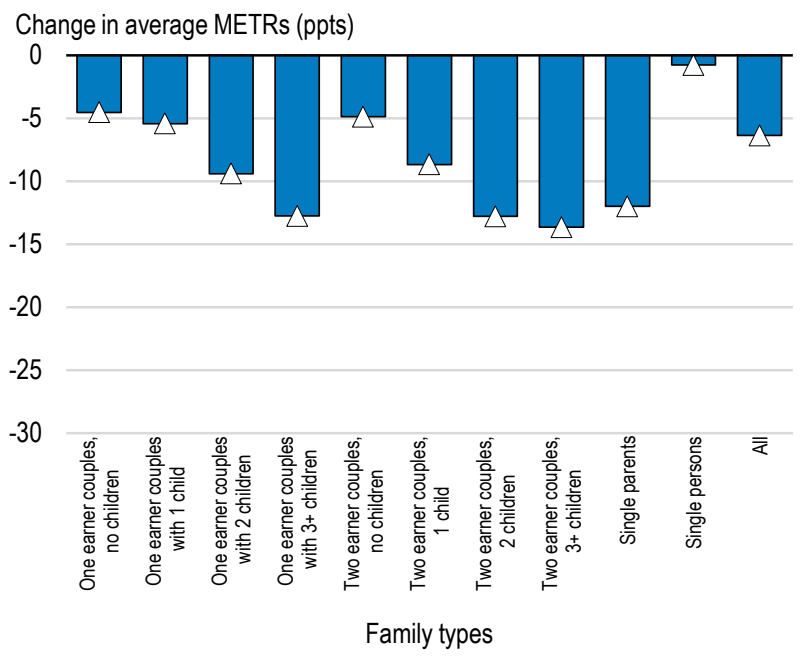

SA Reform: C1 - All

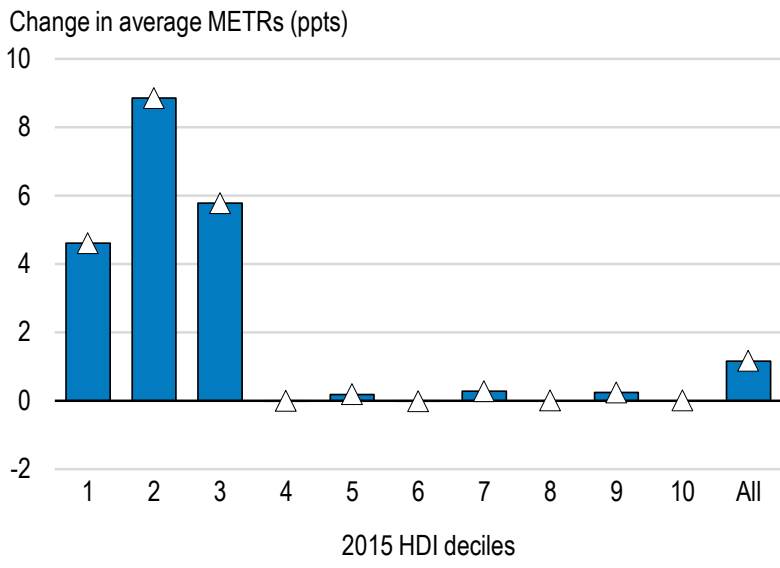

$\triangle$ Total change

SA Reform: C2 - SA recipients

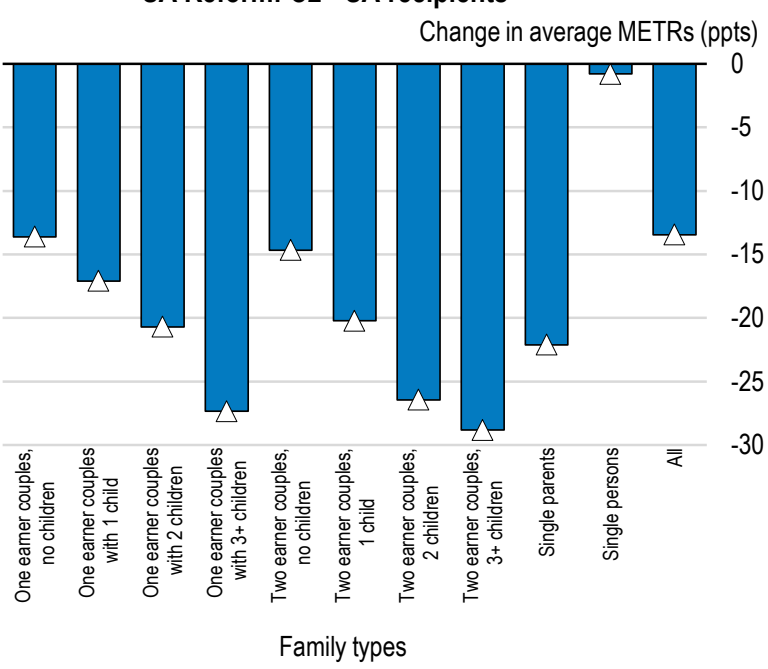

SA Reform: C2 - All

Change in average METRs (ppts)

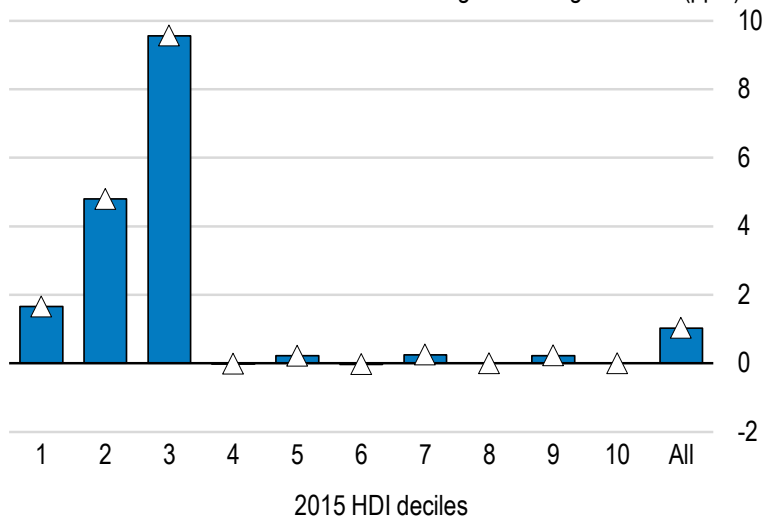

Note: family types: I - for adult, i - for a child, earn- for earner.

\section{Impact of the reform on household disposable income}

58. Both reforms $\mathrm{C} 1$ and $\mathrm{C} 2$ have a positive distributional effect. The increase in disposable income is concentrated in the first income decile and is more than twice as high on average compared to the scenarios introducing income disregards (B1 and B2). This is due to the increase in the SSI level and supplements for children, which are affecting the whole population of social assistance recipients. In contrast, income disregards are only affecting families with at least one employed member. Comparing the two reform scenarios $\mathrm{C} 1$ and $\mathrm{C} 2$, the distributional effect is of a similar magnitude and similarly distributed. The second reform has somewhat larger effects on household disposable income at the lower part of the income distribution. All the family types are better off after the reform due to a combination of the increased SSI level, supplements for children and lower withdrawal rate with earned income. The reform is most beneficial for families with 3 or more children and for single parents. These types of 
families would gain between $2-10 \%$ in relation to their total equivalized household disposable income prereform.

Figure 19. Changes in the eq. household disposable income due to reform

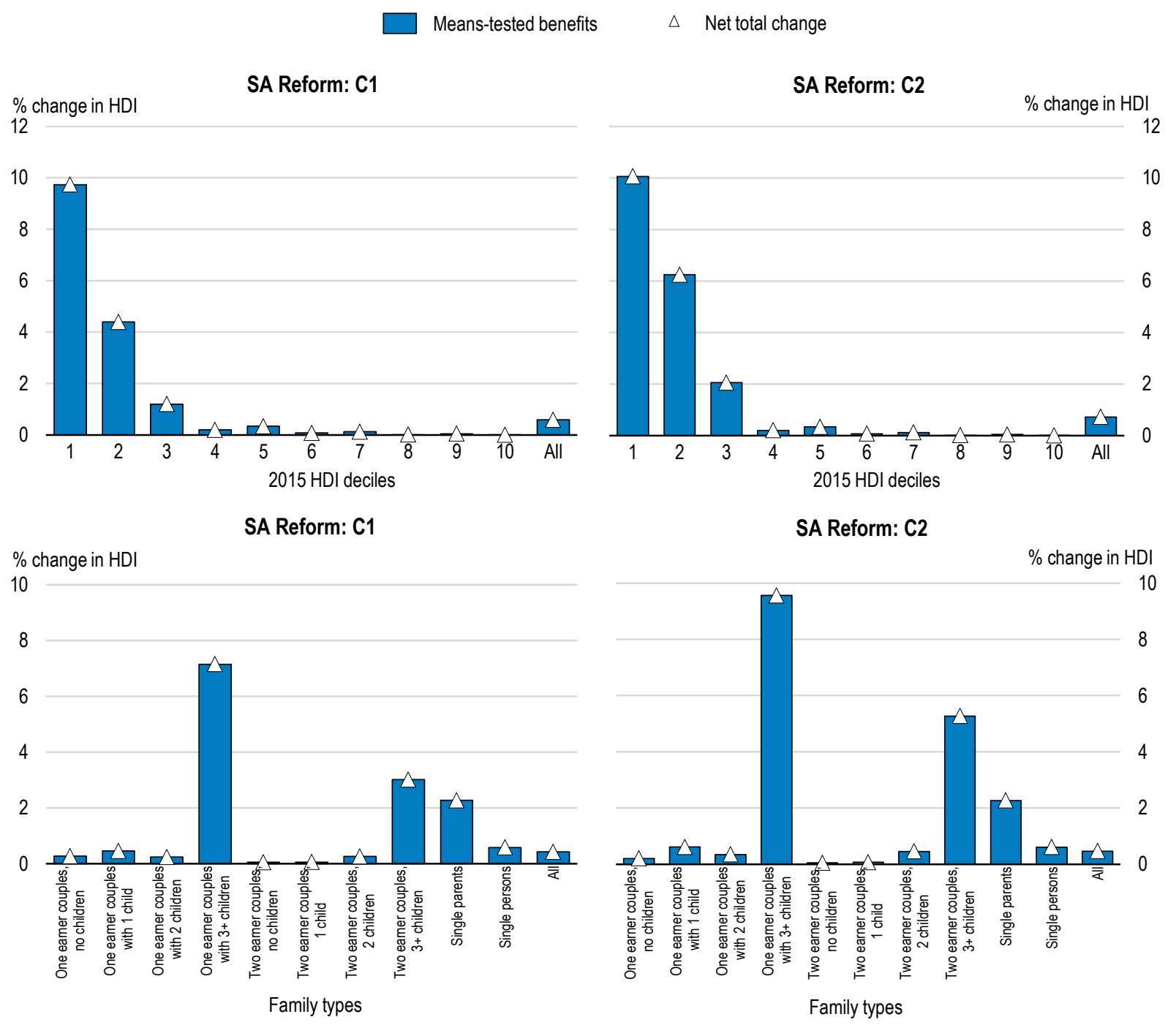

Note: family types: I - for adult, $\mathrm{i}$ - for a child, earn- for earner.

\section{Macro-level costs and benefits}

\section{Impact on the coverage of social protection}

59. According to simulations the unemployment benefit reform would increase the number of benefit recipients by around 13\%. This is due to a less strict requirement of the previous contribution history compared to the current situation (i.e. 12 months during the previous 24 months, instead of 18 months before the previous 36 months). The increase in the coverage of the unemployment benefit system would, however, reduce the number of social assistance claimants, i.e. a more robust system of benefits in unemployment will substitute the need for assistance. 
60. The broadening of the in-work payments (reform A) in the system of cash social assistance for those unemployed who receive social assistance benefits for 6-12 months would potentially double the share of in-work benefit recipients among social assistance recipients. However, the overall number of recipients is expected to remain small given its initial moderate size (i.e. only $2 \%$ of social assistance recipients received in-work-benefits in 2015). The limited impact of the reform on the number of social assistance recipients is related to the fact that those who receive in-work benefits are still counted as social assistance recipients and may still require social assistance as in-work payments expire. Importantly, it should be stressed that our simulations only pick up the first round effects of the reform, while the actual effect may be higher due to behavioural reactions to the increased incentives to seek.

Figure 20. Effects of different scenarios on the number of recipients of out-of-work benefits

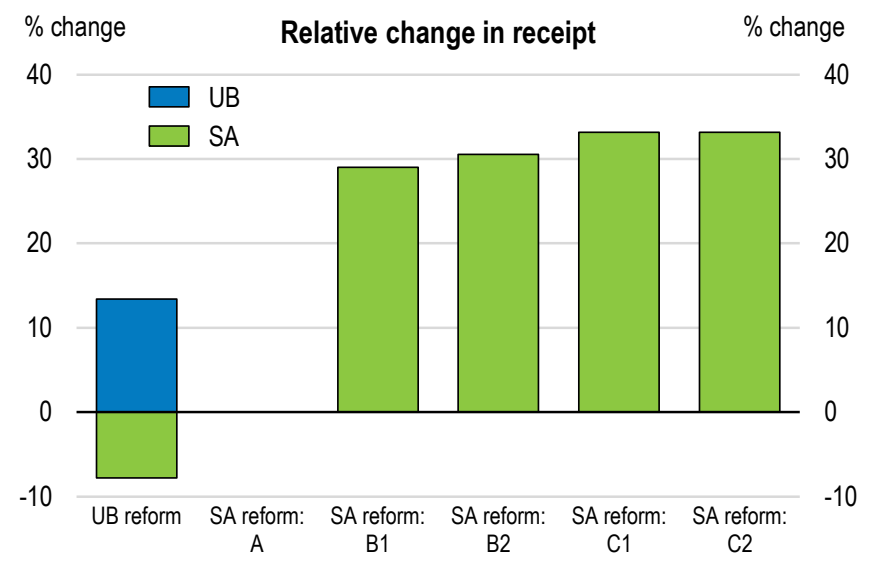

61. Social assistance reforms (B1 and B2) introducing income disregards are expected to substantially increase the number of social assistance recipients (by around 30\%). The increase in the number of recipients happens as the introduction of the income disregard effectively raises the entry and exit threshold of the social assistance system for those families with at least one employed member.

62. Social assistance reforms ( $\mathrm{C} 1$ and $\mathrm{C} 2)$ are expected to increase the number of recipients by around a third. This is due to a combination of an increase in the level of SSI from 102EUR to 130EUR for all social assistance recipients and a lower benefit withdrawal rate with earned income due to the steeper equivalence scales used for estimating the benefit.

\section{Impact on the budgetary cost}

63. Spending on unemployment benefit would potentially double with the reform. This would bring the total level of expenditure on unemployment benefits to about $1 \%$ of the GDP, which is still below the EU average (see Figure 2). The sharp increase in expenditure can be accounted for by the increased benefit replacements rates, duration and extended eligibility. However, the increase in expenditure on unemployment benefits would be to some extent mitigated by a decrease in expenditure on social assistance. Worth noting, the assumption used in our simulations is of full benefit take-up for a maximum duration of payments. Hence the increase in the actual costs may be expected to be lower.

64. The extension of the in-work payments for those unemployed in receipt of social assistance for 612 months does not have any substantial impact on the social assistance payments (due to the reasons explained above). Other social assistance reforms would increase expenditure by around $25 \%$ to $65 \%$. Income disregards (B1 and B2) are estimated to be substantially less costly as these reform scenarios will only affect those social assistance recipients who live in families with at least one employed individual. 
The increase in the level of SSI in conjunction with a steeper equivalence scale and supplements for children would require more funds and affect all recipients of social assistance. The total spending on social assistance after the reform would be in the range of $0.35 \%$ to $0.45 \%$ of the GDP, which is slightly above the EU average (see Figure 2).

Figure 21. Effects of different reform scenarios on expenditure

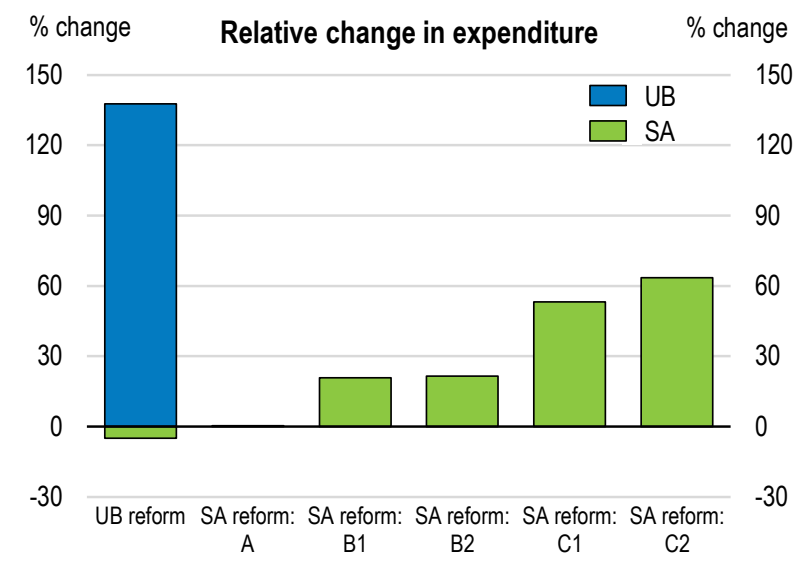

65. All the analysed reforms potentially have a positive effect on reducing the at-risk-of-poverty rate, gap and inequality. Changes in the unemployment benefits have smaller effects on the at-risk of poverty rate and inequality as by design the reform is not targeted at the poor, but at increasing the benefit replacement rates for insured individuals. The unemployment benefit reform only affects positively the poverty rate estimated at the higher threshold of $60 \%$ of the median equivalized household disposable income. This finding is not unexpected as those at the very bottom of the income distribution are mostly not eligible for social insurance payments or their eligibility has expired.

66. The social assistance reforms make a stronger contribution to reduce poverty. Social assistance reforms B1 and B2 as well as $\mathrm{C} 1$ and $\mathrm{C} 2$ are expected to have a substantial first-round effect on reduction of poverty risk rate, gap and inequality. At its highest in scenario $\mathrm{C} 2$, the poverty rate would decrease by around $9 \%$ which would reduce the at-risk-of-poverty indicator by around $1.7 \mathrm{ppts}$. Inequality, as measured by the Gini coefficient, would decrease by up to $2 \%$, implying a decline of the indicator by around 0.7 points. Scenarios B1 and B2 would affect only social assistance recipients who are in work and hence, the effect on the at-risk-of-poverty indicators is less pronounced compared to the reform scenarios $\mathrm{C} 1$ and $\mathrm{C} 2$ that include an increase in the SSI level. 
Figure 22. Potential effects of the reform scenarios on the at-risk-of-poverty gap, rate and inequality

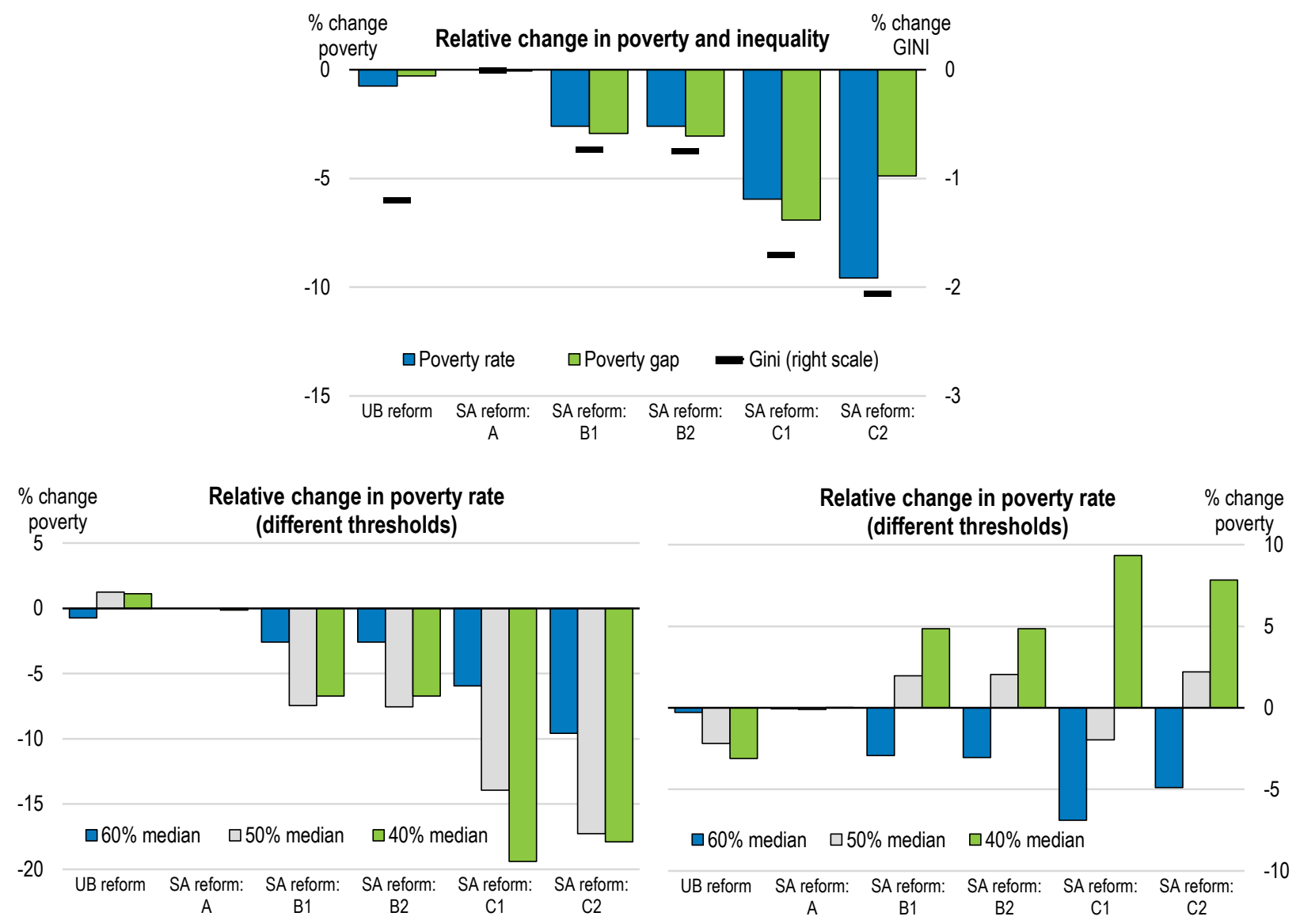

Note: poverty line at $60 \%$ of the median equivalized disposable income

\section{Conclusions}

67. The aim of this paper was to analyse possible reforms of the unemployment and cash social assistance benefits in Lithuania aimed at providing more incentives to participate in the labour market, on the one hand, and delivering decent support for the most in need, on the other. We first analysed a reform of the social insurance unemployment benefit proposed by the Social model reform agenda. A set of possible reforms to social assistance was then investigated ranging from extending the current system of in-work payments (reform A) to the introduction of earnings disregards (reform B1 and B2) and an increase in the level of the state supported income in conjunction with a steeper equivalence scale and supplements for children (reform $\mathrm{C} 1$ and $\mathrm{C} 2$ ). The analysis was based on static micro simulations using EUROMOD, the EU-wide tax-benefit microsimulation model. Financial incentives to take a job are measured by indicators of effective taxation, indicating the share of additional income that is taxed away though direct taxes, social insurance contributions or through benefit withdrawal when increasing labor supply.

68. The proposed reform of unemployment benefits has the potential to raise the benefit's net replacement rates and total household disposable income across the income distribution. Overall, the proposed reform roughly doubles the level of the average annual replacement rate (from around $22 \%$ to around 44\%). In relative terms, the net replacement rates increase most in the upper part of the income 
distribution, due to a stronger link between unemployment benefit entitlements and previous earnings. Both the increased generosity and replacement rates could potentially increase the attractiveness of the unemployment social insurance system, boosting the incentives to participate especially for those with high earnings. Within the context of the widespread shadow economy in Lithuania these effects bring an additional value to the planned reform. Finally, the reforms are expected to reduce income inequalities.

69. While all three proposed social assistance reforms are targeted at increasing work incentives, they all differ in the extent to which they achieve this goal, as well as in the generosity of benefits and affected groups.

70. The extension of the current system of in-work payments towards a group of unemployed recipients of social assistance of 6-12 months (reform A) may add up to around 25\% of the total income for those eligible and with lowest earnings. The number of recipients would potentially double compared to the current system. However, the overall impact would remain limited by the fact that the measure is shortterm and currently covers only a small fraction of those eligible for social assistance (2\%). Nevertheless, the reform would potentially cover a substantial part of social assistance recipients taking a job (one-third currently and more than half in the reform scenario).

71. The establishment of earnings disregards into the system of social assistance in Lithuania (reforms B1 and B2) would have potentially stronger effects. An earnings disregard of $30 \%$ for all social assistance recipients would decrease the marginal effective tax rates among the current social assistance recipients by on average 25 ppts. The lower rate of benefit withdrawal with earned income would make working pay from the first earned euro. The reform would support only the working poor, while those without earnings won't be affected. Working social assistance recipients with dependent members (i.e. children) would benefit most from the reform.

72. The introduction of the steeper equivalence scales would reduce effective taxation of social assistance recipients by 6 ppts on average under the assumption of scenario $\mathrm{C} 1$ and by 13 ppts on average with the steeper scale assumed in scenario $\mathrm{C} 2$. The effect is expected to be stronger for families with children, i.e. result in a drop of the marginal effective tax rate by up to 15 ppts and up to $30 \mathrm{ppts,}$ respectively, for scenarios C1and $\mathrm{C} 2$. Lower levels of social assistance for large families under the assumption of a different equivalence scale are balanced by the introduction of flat-rate child supplements. This allows keeping financial incentives to work as the child supplements are not withdrawn with earned income. Nevertheless flat-rate child supplements introduce a non-linearity to the social assistance system, i.e. a drop in income due to withdrawal of child supplements when income test threshold gets exceeded. This effect is small for the reform $\mathrm{C} 1$ but it becomes more abrupt in scenario $\mathrm{C} 2$, which requires higher child supplements to offset a steeper equivalence scale.

73. Introducing earnings disregards and increasing the level of SSI would potentially come with an increase of the marginal effective tax rate at the country level. This is driven by the fact that some families who are currently not eligible for social assistance become eligible under the less strict income test (i.e. the income test incorporating income disregards or using a higher SSI level). Nevertheless, the effect on the average METR in Lithuania is expected to be small (by around 1 ppts at the aggregate level). On the other hand, the METR would decline significantly for those facing a higher risk of poverty traps in the current system.

74. All the analysed reforms of social assistance and unemployment benefits can potentially contribute to reducing at-risk-of-poverty and inequality rates in Lithuania. However, they require additional expenditure and an expansion of the number of cash benefit recipients. The planned unemployment benefit reform is expected to increase the number of benefit recipients by around $13 \%$ and more than double the total level of expenditure on unemployment insurance benefits (to about $1 \%$ of the 
GDP, which is still below the EU average). Social assistance reforms, except the expansion of the current system of in-work benefits, would have a more profound effect on reducing the level of poverty and inequality. They would require increasing the total spending on social assistance by around 25-65\% depending on the chosen parameters of the reform (i.e. to around $0.35-0.45 \%$ of the GDP, which is slightly above the EU average). They would also generate an increase of around 30\% in the number of recipients.

75. A word of caution needs to be given regarding the limitations of this paper. Most importantly, only the intended first order effects of the reforms are taken into account assuming full benefit take-up and full tax compliance. The effect of the reforms would be lower given there is benefit non take-up or misreporting of income. In particular the use of "envelope wages" in Lithuania implies that earnings related policies such as income disregards may have unwanted effects and requires active policies against fraud to keep the cost of the policy under control and to be sure it will benefit the most vulnerable. On the other hand, more generous unemployment benefits and additional work incentives in the system of social assistance may positively affect labour supply and participation in the legal economy, positively contributing to the effect of the reform and reducing its budgetary cost over the medium-term.

\section{BIBLIOGRAPHY}

Avram, S. (2013), "Outcomes of Social Assistance in Central and Eastern Europe: A Pre-Transfer PostTransfer Comparison”, Institute for Social Economic Research Working Paper, No. 2013-08.

Bourguignon, F., Spadaro, A. (2006). Microsimulation as a tool for evaluating redistribution policies. The Journal of Economic Inequality, Vol. 4(1), p. 77-106.

Demmou L. (2016), "Growing Together : Making the Convergence Process More Inclusive in Lithuania", Economics Department working paper No. 1308, OECD Publishing, Paris, www.oecd.org/eco/surveys/economic-survey-lithuania.htm.

Figari, F., Salvatori, A., Sutherland, H. (2011). 'Economic downturn and stress testing European welfare systems'. Research in Labor Economics 32: 257-286.

Immervoll, H. and S. Scarpetta (2012), "Activation and Employment Support Policies in OECD Countries. An Overview of Current Approaches", IZA Journal of Labour Policy, Vol. 1:9.

Immervoll, H. and M. Pearson (2009), “A Good Time for Making Work Pay? Taking Stock of In-Work Benefits and Related Measures across the OECD", OECD Social, Employment and Migration Working Papers, No. 81, OECD Publishing.

IMF (2014), "Republic of Lithuania: Article IV", IMF Country Report No. 14/113.

Jara, H.X., Tumino, A. (2013). Tax-Benefit Systems, Income Distribution and Work Incentives in the European Union. EUROMOD Working Paper No. EM7/13, p. 37.

Lagenbusher, 2015, "How Demanding are Eligibility Criteria for Unemployment Benefits? Quantitative Indicators for OECD and EU Countries", OECD Social, Employment and Migration Working Papers, No. 166, OECD Publishing. 
Lazutka R., Poviliunas A. (2010). Lithuania: In-work poverty and labour market segmentation. A Study of National Policies. European Commission, DG Employment, p. 37.

Lazutka, R. (2014). The minimum income scheme reform in Lithuania. Ekonomika. Vol. 93(4), pp. 24-40. ISSN 1392-1258.

Lazutka, R., Skučienė, D., Černiauskas, G., Bartkus, A., Navickė, J., Junevičienė, J. (2013). Socialinis draudimas Lietuvoje: kontekstas, raida, rezultatai. LSTC: Vilnius.

MISSOC (2015). Mutual Information System on Social Protection. Information base // MISSOC Comparative Tables Database. Online source: http://www.missoc.org/MISSOC/INFORMATIONBASE /COMPARATIVETABLES/MISSOCDATABASE/comparativeTableSearch.jsp .

Navicke, J. (2015). Between a risk society and a welfare state: social risk resilience and vulnerability to poverty in Lithuania. STEPP: Social theory, empirics, policy and prasctice. Vilnius: Vilnius University, nr. 10., p. 95-109.

Navicke, J., Lazutka, R. (2015). "Work incentives at the bottom of the income distribution and for model families in Lithuania". EUROMOD Working Paper Series EM14/15 .

OECD(2008). "Declaring Work or Staying Underground: Informal Employment in Seven OECD Countries", Employment Outlook 2008, OECD Publishing.

OECD (2013). Framework for Statistics on the Distribution of Household Income, Consumption and Wealth. OECD, online source: http://www.oecd.org/statistics/OECD-ICW-Framework-Chapter8.pdf

OECD (2015a). In it Together: Why less inequality benefits all, OECD publishing.

OECD (2015b). Investing in Youth: Lithuania, OECD publishing.

OECD (2016a). Tax-Benefit Models, Online source: http://www.oecd.org/social/soc/benefits-and-wagesstatistics.htm

OECD (2016b), OECD Economic Surveys: Lithuania 2016: Economic Assessment, OECD Publishing, Paris.

Schneider, F (2015), "Size and Development of the Shadow Economy of 31 European and 5 other OECD Countries from 2003 to 2015: Different Developments", mimeo. http://www.econ.jku.at/members/Schneider/files/publications/2015/ShadEcEurope31.pdf

Socialinis modelis (2015). Darbo santykių ir valstybinio socialinio draudimo teisinis-administracinis modelis Socialinès apsaugos ir darbo ministerija, Vilniaus Universitetas, Mykolio Riomerio Universitetas, Lietuvos Socialinių Tyrimų Centras,77p. Online source: http://www.socmodelis.lt/wpcontent/uploads/Modelio-ataskaita.pdf

Sutherland, H., Figari, F. (2013). EUROMOD: the European Union tax-benefit microsimulation model. International Journal of Microsimulation, 6(1): 4-26. Available at: http://www.microsimulation.org/ijm/issues/volume-61-spring-2013/

Tamašauskienė, Z. (2003). Piniginè socialinė parama Šiaulių mieste ir jos tobulinimas. Ekonomika ir vadyba: aktualijos ir perspektyvos, Vol. 2, pp. 205-210. 


\section{ECO/WKP(2016)34}

Tatsiramos (2009). "Unemployment Insurance in Europe: Unemployment Duration and Subsequent Employment Stability", Journal of the European Economic Association, Vol. 7(6).

UNDP (2010). Darbo paskatu ir priklausomybès nuo paramos priešpastatymo analize pagristos rekomendacijos: dèl trumpalaikiu politikos priemoniu, skirtu Lietuvos socialinés paramos sistemos reformai. Jungtinių Tautų vystymo programa (JTVP) Lietuvoje LR socialinès apsaugos ir darbo ministerija.

Wulfgram and Fervers (2013). "Unemployment and Subsequent Employment Stability: Does Labour Market Policy Matter?”, IZA Discussion Paper, No. 7193.

Zabarauskaitè, R. (2008). Skurdo matavimas ir mažinimo kryptys Lietuvoje. Daktaro disertacija (Ekonomika, 04S). Technika. p.16. 


\section{ANNEX 1: CHARACTERISTICS OF THE CURRENT SYSTEM OF SOCIAL ASSISTANCE, SYSTEM BEFORE 2012 AND ANALYSED REFORM DESIGNS}

Table A1.1. Sum of equivalence scales (eq) applied for calculations of social assistance benefits:

\begin{tabular}{l|c|c|c|c}
\hline \multicolumn{1}{c|}{ Name of the system: } & $\begin{array}{c}\text { Before 2012 } \\
\text { Eq. scale: }\end{array}$ & $\mathbf{2 0 1 5 ~ \& ~ B 1 ~ \& ~ B 2 ~}$ & $\mathbf{C 1}$ & $\mathbf{C 2}$ \\
\hline Single adult & 0.9 & $\mathbf{1}$ & 1 & 1 \\
\hline Couple, no children & 1.8 & $\mathbf{1 . 8}$ & 1.7 & 1.5 \\
Couple, 1 child & 2.7 & $\mathbf{2 . 5}$ & 2.2 & 1.8 \\
Couple, 2 children & 3.6 & $\mathbf{3 . 2}$ & 2.7 & 2.1 \\
Couple, 3 children & 4.5 & $\mathbf{3 . 9}$ & 3.2 & 2.4 \\
Couple, 4 children & 5.4 & $\mathbf{4 . 6}$ & 3.7 & 2.7 \\
\hline Single, 1 child & 1.8 & $\mathbf{1 . 8}$ & 1.5 & 1.3 \\
Single, 2 children & 2.7 & $\mathbf{2 . 5}$ & 2 & 1.6 \\
Single, 3 children & 3.6 & $\mathbf{3 . 2}$ & 2.5 & 1.9 \\
Single, 4 children & 4.5 & $\mathbf{3 . 9}$ & 3 & 2.2 \\
\hline
\end{tabular}

Source: calculations by the authors. Note: more generous scale in green, less generous scale in red.

Table A1.2. Maximum amount of social assistance benefit (SSI*eq) and withdrawal rate for an earned EUR (eq / n):

\begin{tabular}{|c|c|c|c|c|c|c|c|c|c|c|}
\hline & $\begin{array}{c}\text { Before } \\
2012 \\
\end{array}$ & 2015 & $\begin{array}{l}\text { B1, } \\
\text { B2 }\end{array}$ & C1 & C2 & $\begin{array}{c}\text { Before } \\
2012 \\
\end{array}$ & 2015 & $\begin{array}{c}\text { B1, } \\
\text { B2 }\end{array}$ & C1 & $\mathrm{C} 2$ \\
\hline Single & 91.8 & 102 & 102 & 130 & 130 & $90 \%$ & $100 \%$ & $70 \%$ & $100 \%$ & $100 \%$ \\
\hline Couple, 0 ch. & 183.6 & 183.6 & 183.6 & 221 & 195 & $90 \%$ & $90 \%$ & $63 \%$ & $85 \%$ & $75 \%$ \\
\hline Couple, $1 \mathrm{ch}$. & 275.4 & 255 & 255 & 286 & $234+30$ & $90 \%$ & $83 \%$ & $58 \%$ & $73 \%$ & $60 \%$ \\
\hline Couple, 2 ch. & 367.2 & 326.4 & 326.4 & 351 & $273+60$ & $90 \%$ & $80 \%$ & $56 \%$ & $68 \%$ & $53 \%$ \\
\hline Couple, 3 ch. & 459 & 397.8 & 397.8 & $416+20$ & $312+90$ & $90 \%$ & $78 \%$ & $55 \%$ & $64 \%$ & $48 \%$ \\
\hline Couple, $4 \mathrm{ch}$. & 550.8 & 469.2 & 469.2 & $481+20$ & $351+120$ & $90 \%$ & $77 \%$ & $54 \%$ & $62 \%$ & $45 \%$ \\
\hline Single, 1 ch. & 183.6 & 183.6 & 183.6 & $195+20$ & $169+30$ & $90 \%$ & $90 \%$ & $63 \%$ & $75 \%$ & $65 \%$ \\
\hline Single, 2 ch. & 275.4 & 255 & 255 & $260+20$ & $208+60$ & $90 \%$ & $83 \%$ & $58 \%$ & $67 \%$ & $53 \%$ \\
\hline Single, 3 ch. & 367.2 & 326.4 & 326.4 & $325+20$ & $247+90$ & $90 \%$ & $80 \%$ & $56 \%$ & $63 \%$ & $48 \%$ \\
\hline Single, 4 ch. & 459 & 397.8 & 397.8 & $390+20$ & $286+120$ & $90 \%$ & $78 \%$ & $55 \%$ & $60 \%$ & $44 \%$ \\
\hline
\end{tabular}

Source: calculations by the authors. Note: better-off situation in green (higher assistance / lower withdrawal rate), worse-off situation in red (lower assistance / higher withdrawal rate). 


\section{ANNEX 2: INDICATORS OF FINANCIAL INCENTIVES TO WORK AT THE EXTENSIVE MARGIN: SCENARIOS B AND C}

Figure A2.1. METR2 for transition from the observed level of earnings to the minimum wage, by family type (Income disregards scenarios: B1 and B2)

SA Reform: B1 - SA recipients

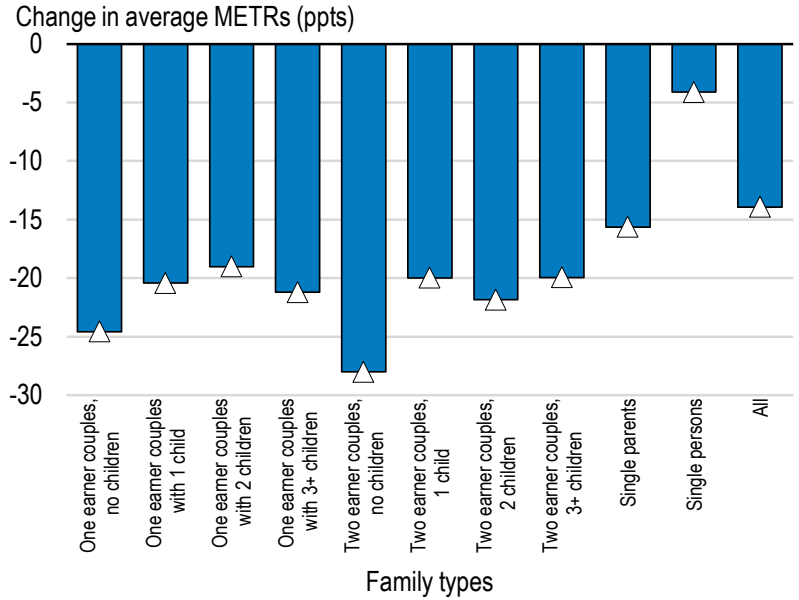

SA Reform: B2 - SA recipients

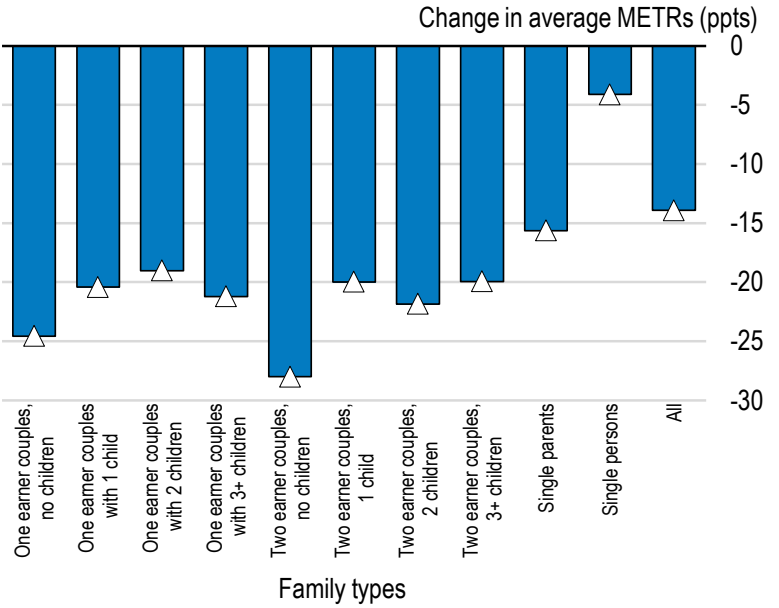

Note: family types: I - for adult, $\mathrm{i}$ - for a child, earn- for earner.

The effect of income disregards on the extensive margin is similar to the one at the intensive margin. However, singles benefit much less. This is due to the low level of the SSI. While the earnings disregards makes the income test less strict (i.e. at around 130EUR for a single person), this level is much below compared to the level of the minimums wage. The current rules of social assistance in Lithuania require a potential social assistance recipient to be employed for no less than $3 / 4$ of time, which implies that single persons without dependents can in practice only be eligible for social assistance if unemployed.

Figure A2.2. METR2 for transition from the observed level of earnings to the minimum wage, by family type (third scenario: C1 and C2)

10

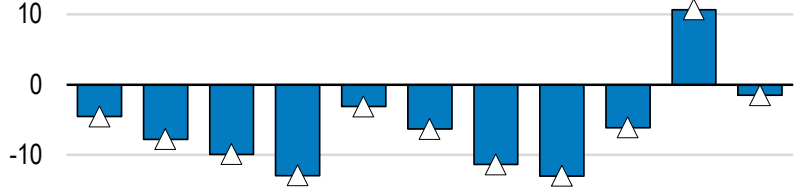

$-20$

$-30$

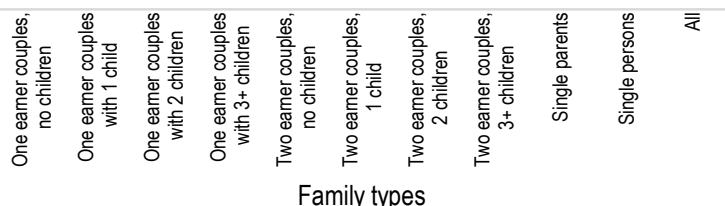

Note: family types: I - for adult, $\mathrm{i}$ - for a child, earn- for earner.

SA Reform: C2 - SA recipients Change in average METRs (ppts)
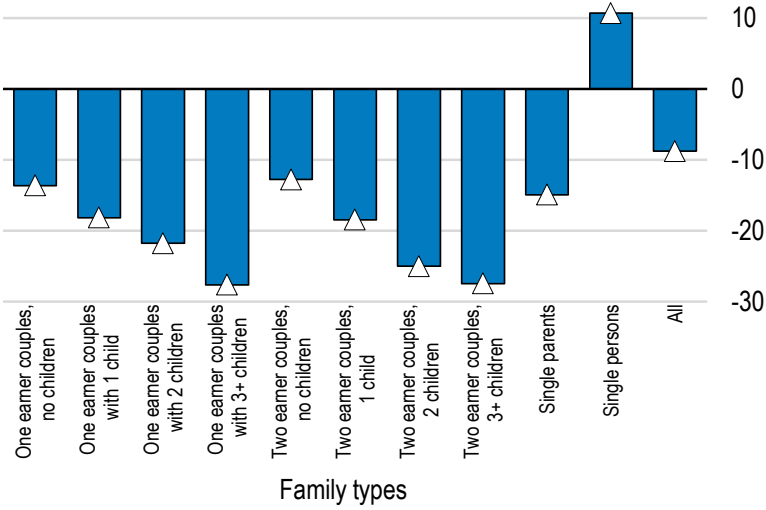
The impact of the reform on marginal effective tax rates when earnings are increased for the recipients of social assistance from their current level to that of the monthly full-time minimum wage implies a decrease of the METR among social assistance recipients across most family types. The exception is single individuals, for whom the METR increase as the higher amount of social assistance is withdrawn due to increase in the SSI level from 102EUR to 130EUR. 